Saint Louis University School of Law

Scholarship Commons

All Faculty Scholarship

2012

Undo Undue Hardship: An Objective Approach to Discharging

Federal Students Loans in Bankruptcy

Aaron N. Taylor

Follow this and additional works at: https://scholarship.law.slu.edu/faculty

Part of the Bankruptcy Law Commons, Education Law Commons, and the Inequality and Stratification Commons 


\section{S A I N T L O U I S}

$\begin{array}{llllllllll}U & N & \text { I } & V & E & R & S & \text { I } & T & Y\end{array}$

\section{SCHOOL OF LAW}

\section{SAINT LOUIS UNIVERSITY SCHOOL OF LAW Legal Studies Research Paper Series}

No. $2012-14$

Undo Undue Hardship: An Objective Approach to Discharging Federal Students Loans in Bankruptcy

Aaron N. Taylor

Working Paper 


\title{
UNDO UNDUE HARDSHIP: AN OBJECTIVE APPROACH TO DISCHARGING FEDERAL STUDENT LOANS IN BANKRUPTCY
}

\begin{abstract}
Aaron N. Taylor*
A debtor seeking to discharge student loans in bankruptcy must prove that paying the debt would cause an undue hardship upon him and his dependents. Undue hardship, however, is an undefined concept, flummoxing debtors, creditors, and judges alike. The result of this ambiguity is rampant inconsistency in the manners in which similarlysituated debtors (and creditors) are treated by the courts. This Article argues that the undue hardship standard should be replaced by a framework that uses debt service thresholds to determine the propriety of federal student loan bankruptcy discharges. Eligibility for discharge would depend on outstanding loan amounts, debtor income history, federal poverty guidelines, and the type of academic program in which the loan was incurred. The goals of the framework would be two-fold: 1) to provide an impartial, economical, and uniform means of assessing the propriety of federal student loan discharges, and 2) to provide debtors facing crushing student loan debt and few prospects for repaying it with a simplified avenue of relief in bankruptcy.
\end{abstract}

\section{TABLE OF CONTENTS}

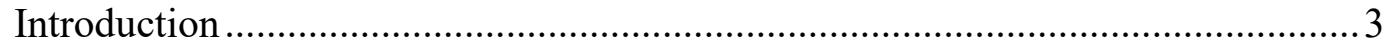

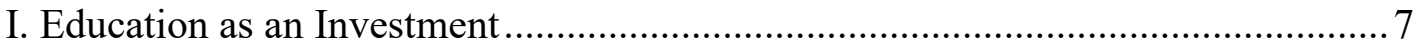

A. Salary Differences ............................................................................ 8

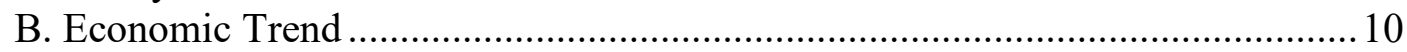

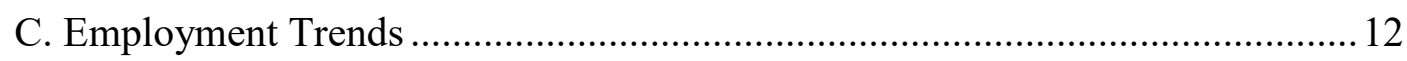

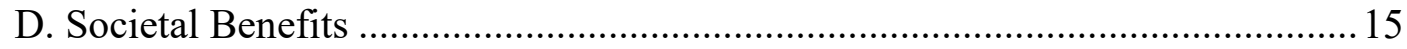

*Assistant Professor of Law, Saint Louis University School of Law. B.A., North Carolina A\&T State University; J.D., Howard University School of Law; Ed.D., Vanderbilt University. The author would like to thank Theresa M. Beiner, Matthew T. Bodie, Michael Korybut, David Lander, Efthimios Parasidis, and Lisa S. Taylor for their helpful feedback on earlier drafts of the article. He thanks Nnamdi Nnedu and Alexandra Rodery for their research assistance. He dedicates the article to his grandmother, Mariah Whitehurst. Any errors or misstatements are the author's alone. 


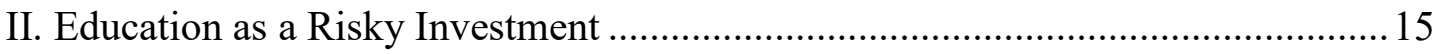

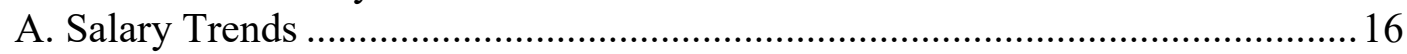

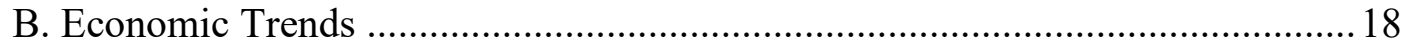

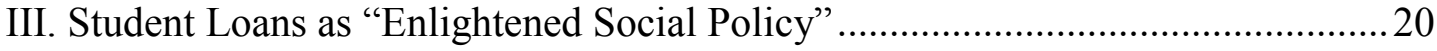

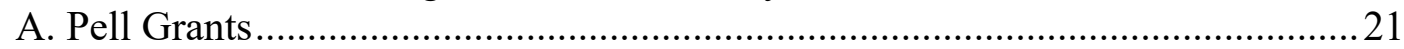

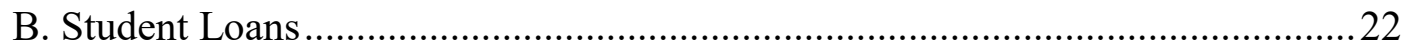

C. Increased College Participation.................................................................... 24

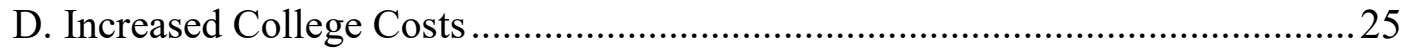

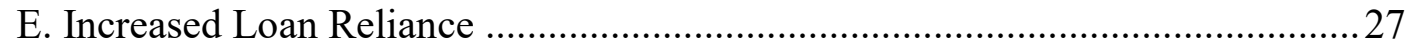

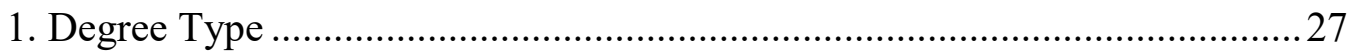

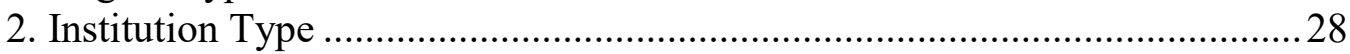

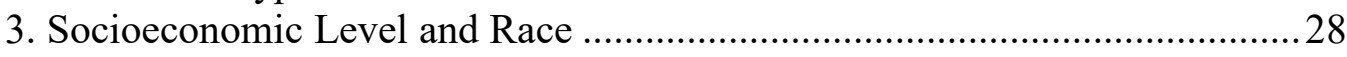

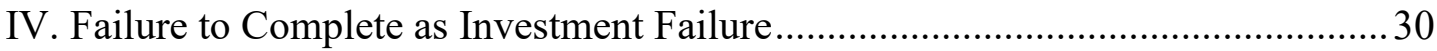

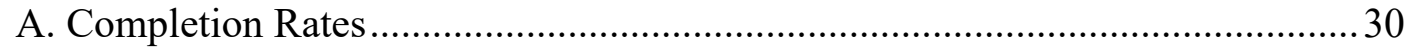

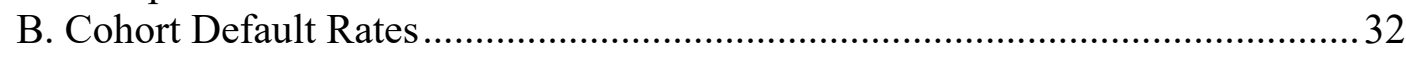

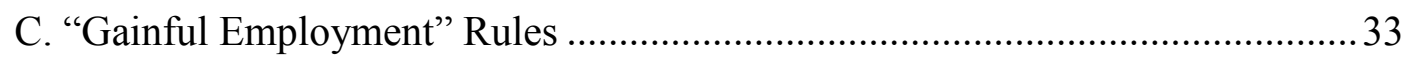

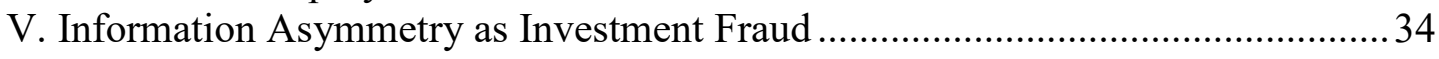

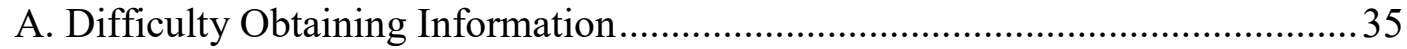

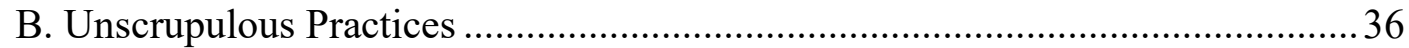

1. Few Avenues for Redress....................................................................... 38

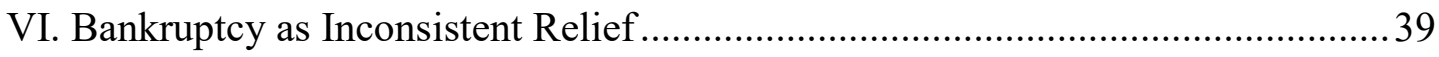

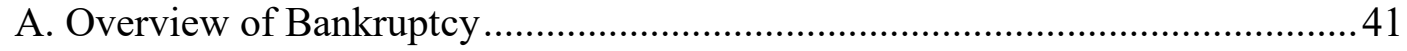

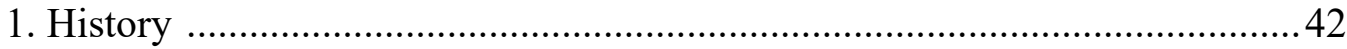

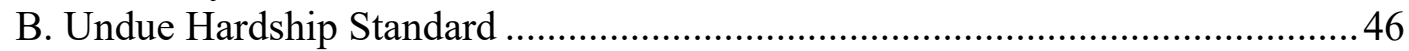

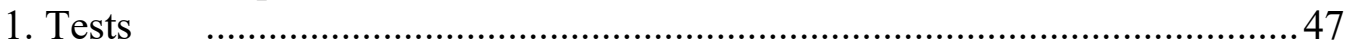

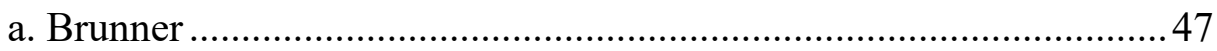

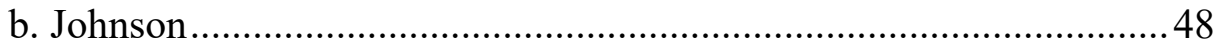

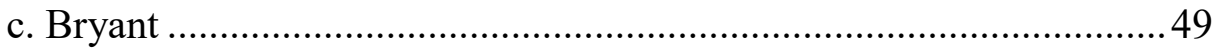

d. Totality of Circumstances ......................................................... 49

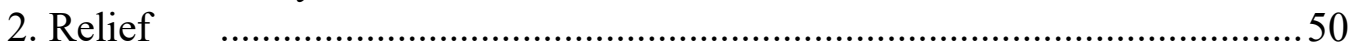

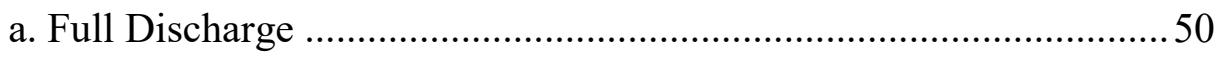

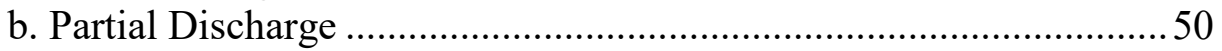

c. Hybrid Discharge ......................................................................... 51

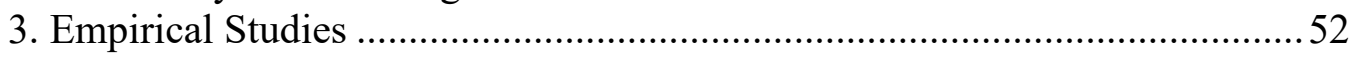

VII. Debt Service Thresholds as Objective Benchmarks ...................................... 54

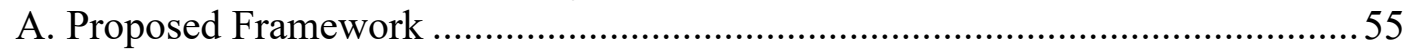

1. Mandatory Repayment Periods ............................................................. 56

2. Participation in an Income-Based Repayment Plan .................................55

3. Maximum Debt Service Thresholds..........................................................5 57

4. Five Years of Above-Maximum Payments ..................................................5 59

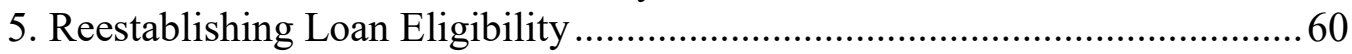

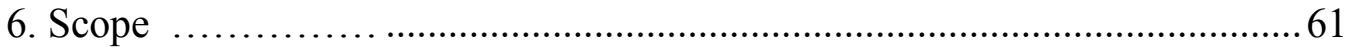




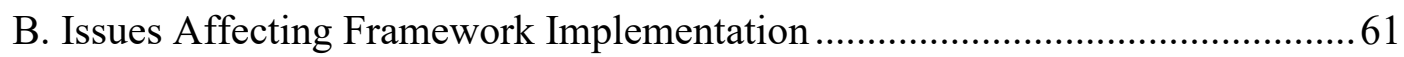

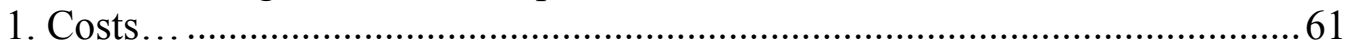

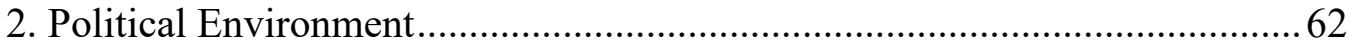

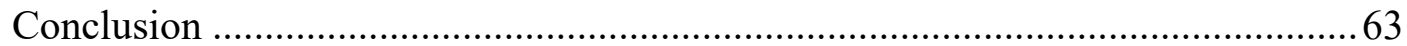

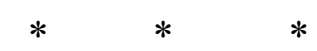

INTRODUCTION

What does undue hardship mean?

Poverty or something less extreme?

The standard Congress left undefined

Prompting both debtors and creditors to whine

Judges have been given the difficult task

Of making sense of the mess at hand

Selecting which test should be imposed

Brunner? Johnson? Totality? Who knows?!

Should debtor good faith play a part?

What about debtor's right to a fresh start?

And in cases where hardship is undue,

Does full, partial, or hybrid discharge ensue?

Just some of the questions that come to mind,

Due to the standard left undefined

So with clarity and fairness overrun

Undue hardship should be undone. ${ }^{1}$

When Congress first imposed the undue hardship standard upon debtors seeking to discharge student loans in bankruptcy, it intended the standard to be the final barrier against debtor abuse. ${ }^{2}$ Congress reasoned that the very viability of the federal student loan program required that only honest debtors receive relief. ${ }^{3}$ Through the years, however, Congress fashioned the

\footnotetext{
${ }^{1}$ This fit of artistic indulgence was inspired by a bankruptcy judge's poetic means of lamenting the "unusual and confusing language" contained in the automatic dismissal provision of 11 U.S.C. $\S 521$. In re Riddle, 344 B.R. 702, 703 (Bankr. S.D. Fla. 2006). ${ }^{2} 156$ CONG. REC. E570 (2010) (statements of Rep. Steve Cohen) [hereinafter Cohen Remarks] ("Congress's intent in enacting [the undue hardship] provision back in 1978 was to protect Federal student loan programs from fraud and abuse by student borrowers and ultimately to protect the taxpayer dollars that fund Federal student loan programs.").

${ }^{3}$ Id.; see also, e.g., Claxton v. Student Loan Mktg. Ass'n (In re Claxton), 140 B.R. 565, 570 (Bankr. N.D. Okla. 1992) (reasoning that when debtors repay student loans, "they are
} 
undue hardship barrier into a bulwark, representing the sole means of getting student loans discharged in bankruptcy. ${ }^{4}$ But while repeatedly increasing the standard's prominence, Congress failed to increase its clarity.

Undue hardship is an undefined concept, flummoxing debtors, creditors, and judges alike. ${ }^{5}$ The result of its ambiguous contours is rampant inconsistency. Judges define the standard differently, ${ }^{6}$ they impose different conceptual tests on debtors, ${ }^{7}$ and when undue hardship is found, relief is often dependent upon judicial philosophy rather than the merits of the case. ${ }^{8}$ In the end, similarly-situated debtors (and creditors) are treated differently based on the courts in which they find themselves, leaving an irony where inconsistency is the most consistent aspect of the standard's application.

Inconsistency is not the only shortcoming of the undue hardship standard. The premise underlying the standard's purpose is also illegitimate. In the $1970 \mathrm{~s}$, the media began to tap into concern about the "rising tide of bankruptcies", 9 and sensational stories about doctors and lawyers receiving student loan discharges "on the eve of embarking on lucrative careers" began to damage public perceptions of the loan program. ${ }^{10}$ In response, Congress restricted the circumstances in which

helping to make education available for others," and therefore Congress intended for student loan debtors' right to relief to "yield to some extent").

${ }^{4}$ See generally B.J. Huey, Comment, Undue Hardship or Undue Burden: Has the Time Finally Arrived for Congress to Discharge Section 523(a)(8) of the Bankruptcy Code?, 34 TEX. TECH L. REV. 89 (2002) (providing a history of student loan discharge provisions).

${ }^{5}$ In re Claxton, 140 B.R. at 568 ("[T] he Bankruptcy Code does not define 'undue hardship;' and it is not clear exactly what it is that debtors must prove.").

${ }^{6}$ Compare Skaggs v. Great Lakes Higher Educ. Corp. (In re Skaggs), 196 B.R. 865, 867

(Bankr. W.D. Okla 1996) (reasoning that "undue hardship" should be defined using "the plain, ordinary meaning of those words"), with Heckathorn v. United States ex rel. U.S. Dep't of Educ. (In re Heckathorn), 199 B.R. 188, 194-95 (Bankr. N.D. Okla. 1996)

("Although the words 'undue' and 'hardship' are common English words, their combination in this statute obviously constitutes a term of art, i.e., a phrase with a particular legal meaning and function, which is based on but may be more specialized than common usage.").

${ }^{7}$ Kopf v. U.S. Dep't of Educ. (In re Kopf), 245 B.R. 731 (Bankr. D. Me. 2000) (discussing the predominant tests courts use to determine undue hardship).

${ }^{8}$ See, e.g., Grigas v. Sallie Mae Servicing Corp. (In re Grigas), 252 B.R. 866, 870-74

(Bankr. D. N.H. 2000) (providing overview of three judicial approaches to student loan discharge: full, partial, and hybrid).

${ }^{9}$ H.R. Doc. No. 93-137, pt. 1, at 2 (1973) ("The most dramatic fact about bankruptcy administered under the present Act is the rising tide of bankruptcies since World War II.").

${ }^{10}$ Frank T. Bayuk, Comment, The Superiority of Partial Discharge for Student Loans Under 11 U.S.C. $\{$ 523(A)(8): Ensuring a Meaningful Existence for the Undue Hardship Exception, 31 FLA. ST. U. L. REV. 1091, 1094 (2004). 
student loans could be discharged, making loans non-dischargeable within the first five years of repayment, ${ }^{11}$ but still dischargeable thereafter. Accompanying this new restriction was an exception that allowed for loans in repayment for less than five years to be discharged in cases where a debtor could prove that paying the loans would cause an undue hardship upon him and his dependents. ${ }^{12}$ In the years to follow, Congress would lengthen and eventually remove the period of mandatory repayment, making the undue hardship exception the only path to student loan discharge. ${ }^{13}$ This gradual tightening was premised on preventing abuse of the bankruptcy system and the student loan program by crafty debtors. ${ }^{14}$ However, the anecdotal evidence on which Congress relied has not held up to empirical scrutiny. ${ }^{15}$

The undue hardship standard has another deleterious effect: it makes it difficult for debtors to discharge debt incurred as a result of lack of information or misinformation about educational offerings. Most students choose a college based on very limited information. Information regarding school quality is sparse and, where it exists, often inscrutable. ${ }^{16}$ Additionally, information regarding the financial implications of attending college often comes too late, if at all. ${ }^{17}$ The resulting "information

${ }^{11}$ NAT'L BANKR. REVIEW COMM'N, BANKRUPTCY: THE NEXT TwENTY YEARS 207 (1997), http://govinfo.library.unt.edu/nbrc/reportcont.html (follow links to relevant sections) [hereinafter COMMISSION REPORT1997].

${ }^{12} I d$. at 209.

${ }^{13}$ See generally Huey, supra note 4 (providing a history of student loan discharge provisions).

${ }_{15}^{14}$ See, e.g., Cohen Remarks, supra note 2, at E570.

${ }^{15}$ See, e.g., H.R. Doc. No. 93-137, pt. 1, at 53-54 ("Notwithstanding the notoriety of 'scam' bankruptcies, absconding and concealing debtors, and other instances of egregious conduct in, and in anticipation of, cases under the Act, the Commission has found little empirical substantiation that dishonest conduct is a cause of bankruptcy in a significant number of cases."); $c f$. COMMISSION REPORT 1997, supra note 11, at 82 ("But the statistical evidence suggests that consumers who file for bankruptcy today, as a group, are experiencing a financial crisis similar to the crisis faced by families when filing rates were only a fraction of their present levels.").

${ }^{16}$ Bridget Terry Long, CTR. For AM. Progress, Grading Higher EduCATION: Giving CONSUMERS THE INFORMATION THEY NEED 1 (2010), available at http://www.americanprogress.org/issues/2010/12/pdf/longpaper.pdf (“[T]he process of college choice involves simultaneously ranking options in multiple ways, relying on incomplete and uncertain information, and receiving little or no support for interpreting the facts that are available.").

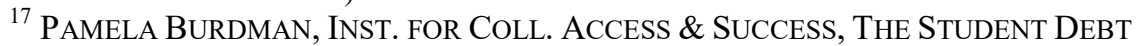
DILEMMA: DeBt AVERSION AS A BARRIER TO COLLEGE ACCESS 9 (2005), available at http://projectonstudentdebt.org/files/pub/DebtDilemma.pdf ("There is no clear or established division of labor between high school officials, admissions and outreach offices and financial aid offices that ensures students receive the information they need when they 
asymmetry"18 creates an environment where students are more susceptible to bad educational matches ${ }^{19}$ or to being victimized by misrepresentations or other improprieties. ${ }^{20}$ When a student attends a school based on lack of information or, worse yet, false information, her chances of completing the program are diminished. ${ }^{21}$ And unfortunately, students who leave college without earning a credential are often saddled with student loan debt that they will likely have difficulty repaying. ${ }^{22}$

Few courts consider the value of the education received when making undue hardship determinations. ${ }^{23}$ The reasoning behind this approach is that the federal government is not "an insurer of educational value." ${ }^{24}$ It has also been argued that a student loan is an individual investment, and therefore, the taxpayers should not be held responsible if the investment fails to pay off. ${ }^{25}$ However, victims of higher education misrepresentations are offered few avenues for redress by the courts or by regulatory agencies. ${ }^{26}$ Courts are reluctant to recognize certain types of claims against educational institutions. ${ }^{27}$ Regulatory agencies are more concerned with

need it.").

${ }^{18}$ The term "information asymmetry" denotes the difference in access to information between education providers and education consumers. David D. Dill, Allowing the Market to Rule: The Case of the United States, 57 HIGHER EDUC. Q. 136, 147 (2003).

${ }^{19}$ LONG, supra note 16, at 9 ("Without easily obtainable information and a clear map of the key factors worth considering and how to process them, there are many examples of decisions that probably represent 'bad matches."').

${ }^{20}$ Dill, supra note 18 , at 147 ("[B] ecause higher education in the US is an industry in which consumers cannot objectively evaluate the quality of the service before they purchase it, an information asymmetry can exist in which institutions may take advantage of consumers.").

${ }^{21}$ Brian A. Jacob \& Tamara Wilder, Educational Expectations and Attainment 18 (Nat'l Bureau of Econ. Research, Working Paper No. 15683, 2010) ("The fact that most students attain less education than they expect ... suggests that misinformation is the cause of the gap.").

${ }_{22}$ See LONG, supra note 16, at 9 ("[A]lmost half of college students who attend a four-year institution fail to get a degree. Meanwhile, these students carry significant amounts of student debt that is not likely to be justified without receipt of a college credential.").

${ }^{23}$ The Brunner test is the dominant undue hardship test. The court in Brunner argued that "[c]onsideration of [educational value] . . is antithetical to the spirit of the guaranteed loan program.” Brunner v. New York State Higher Educ. Servs. Corp. (In re Brunner), 46 B.R. 752, 755 n.3 (Bankr. S.D.N.Y. 1985).

${ }^{24} I d$.

${ }^{25}$ Id. at $755-56$ n. 3

${ }^{26}$ See Aaron N. Taylor, "Your Results May Vary”: Protecting Students and Taxpayers Through Tighter Regulation of Proprietary School Representations, 62 ADMIN. L. REV. 729 (2010).

${ }^{27} I d$. at 763 (explaining how the judicial concept of academic abstention disadvantages plaintiffs in lawsuits against educational institutions). 
protecting public interests than those of individuals. ${ }^{28}$ Thus, in order to provide some level of protection to students who receive little monetary benefit from their educational experiences, whether because of impropriety or simple misfortune, bankruptcy discharge should be a viable avenue of relief from the burdens of student loan debt.

This Article argues that the undue hardship standard should be undone, replaced by a bright-line rule that uses debt service thresholds to determine the propriety of federal student loan bankruptcy discharges. ${ }^{29}$ Educational value plays a central role in the proposed framework, as eligibility for discharge would depend on outstanding loan amounts, debtor income history, federal poverty guidelines, and the type of academic program in which the loan was incurred. The goals of the framework would be twofold: 1) to provide an impartial, economical, and uniform means of assessing the propriety of student loan discharges, and 2) to provide debtors facing crushing student loan debt and few prospects for repaying it with a simplified avenue of relief in bankruptcy.

The Article begins, in Part I, with a discussion of the factors that have made post-secondary education virtually obligatory, including how salary and labor market trends engender an investment mindset among students. Part II describes the speculative nature of educational investments. Part III documents the trend towards increased education borrowing. Part IV discusses the dismal educational outcomes that contribute to student loan over-indebtedness. Part V explains how lack of information and misinformation influence students' educational decisions. Part VI highlights inconsistency and ambiguity in bankruptcy law, particularly in the area of student loan discharge. And finally, Part VII presents the framework for using debt service thresholds to determine the propriety of student loan bankruptcy discharges.

\section{I: EDUCATION AS AN INVESTMENT}

We have all heard the axiom: Education pays. This simple declaration serves as a compelling justification for undertaking - and in the process, investing in-higher education. It is frequently the title encapsulation of studies, ${ }^{30}$ reports, ${ }^{31}$ and news articles ${ }^{32}$ extolling the virtues

\footnotetext{
${ }^{28}$ Id. at 731 .

${ }^{29}$ Currently, the undue hardship standard is applied to private student loans in the same manner it is applied to federal loans in bankruptcy. However, the framework proposed in this article would only apply to federal student loans for reasons discussed in VII.A.6.

${ }^{30}$ E.g., SANDY BAUM, ET AL., COLl. BD. AdvOCACY \& POliCY CTR.,EDUCATION PAYs 2010: THE BENEFITS OF HIGHER EDUCATION FOR INDIVIDUALS AND SOCIETY (2010),
} 
of education. If higher education was a company, "Education Pays" would be its "Just do it." A review of relevant data shows that education does indeed pay - on a wide range of quality-of-life indicators. Higher levels of education are associated with various job-related benefits, including higher salaries, ${ }^{33}$ better fringe benefits, ${ }^{34}$ and more job satisfaction. ${ }^{35}$ Education has also been tied to better health, ${ }^{36}$ increased parental effectiveness, ${ }^{37}$ and greater civic behavior. ${ }^{38}$

\section{A. Salary Differences}

The decision to undertake higher education has been termed the "Million Dollar Question". 39 This characterization references the oft-cited difference in lifetime earnings between a college graduate and a high school graduate. ${ }^{40}$ Research has concluded that over the span of a 40 -year career, college graduates will earn about sixty-six percent more in salary than high school graduates. $^{41}$ According to the Bureau of Labor Statistics (BLS), the median weekly pay for bachelor's degree-holders is $\$ 1,053$, while the median for high school graduates is $\$ 638 .{ }^{42}$ These degree-based salary differences get larger as the comparisons get starker. For example, the median salary for professional degree-holders is almost four times the median for individuals with less than a high school diploma. ${ }^{43}$ Also, the

available at http://trends.collegeboard.org/downloads/Education_Pays_2010.pdf.

${ }^{31}$ See, e.g., Employment Projections: Education Pays, BurEAU LAB. STAT. (last modified March 23, 2012), http://www.bls.gov/emp/ep_chart_001.htm.

${ }^{32}$ See, e.g., Jack Z. Smith, A Simple Lesson: Education Pays, SPOKESMAN-REVIEW, March 17, 2009, http://www.spokesman.com/stories/2009/mar/17/a-simple-lesson-educationpays/.

${ }_{33}$ See BAUM, ET AL., supra note 30, at 10.

${ }^{34}$ See id.

${ }^{35}$ Philip Oreopoulos \& Kjell G. Salvanes, How Large are Returns to Schooling? Hint: Money Isn't Everything 8 (Nat'l Bureau of Econ. Resarch, Working Paper No. 15339, 2009).

${ }^{36} \mathrm{Id}$. at 10 .

${ }^{37} \mathrm{Id}$. at 12.

${ }^{38}$ See BAUM ET AL., supra note 30, at 10.

${ }^{39}$ Harvard researcher Bridget Terry Long coined this term as part of her research into college graduation rates. Answering the Million-Dollar Question: The Problem of College Attrition-Could Institutions Do More?, HGSE NEWs, Apr. 16, 2003, http://www.gse.harvard.edu/news/features/long04152003.html.

${ }^{40} \mathrm{Id}$.

${ }^{41}$ BAUM ET AL., supra note 30, at 12.

${ }^{42}$ BUREAU LAB. STAT., supra note 31.

${ }^{43}$ Median weekly pay for professional degree-holders is $\$ 1,665$ compared to $\$ 451$ for less than a high school diploma. $I d$. 
wage premiums associated with schooling increase as time in school increases. The first year of college is associated with an $11 \%$ median increase in earnings; the fourth year of college is associated with a $16 \%$ increase; and the second year of graduate or professional school is associated with a $19 \%$ increase. $^{44}$

The data suggests that the salary benefits of education appear early in an individual's career. Among workers aged 25-34, bachelor's degreeholders make 50\% more than high school graduates. ${ }^{45}$ As such, an individual is able to account for income lost while in school relatively early in her career. At median salary levels, it has been estimated that it takes bachelor's degree holders about eleven years to recoup expenses related to earning the degree, including actual expenses and lost salary. ${ }^{46}$ This means that the typical bachelor's degree-holder "breaks even" on her education investment barely a quarter of the way into her 40-year career.

The earnings premium on education has grown over the last thirty years. During the period from 1980 to 2005, the earnings premium of a college degree (compared to a high school diploma) increased $22 \%{ }^{47}$ Another study found that the earnings premium between college and high school educated workers increased 30\% between 1963 and 2009, albeit fitfully. ${ }^{48}$ Even after accounting for race and years of work experience, researchers conclude that earnings premium trends hold. ${ }^{49}$

${ }^{44}$ BAUM ET AL., supra note 30, at 17.

${ }^{45}$ Susan Aud, ET Al., NAT’L CTR. FOR Educ. Stat., U.S. DePt. Of EduC., The Condition OF EDUCATION 2011, at 56 (2011), http://nces.ed.gov/pubs2011/2011033.pdf ("[Y]oung adults with a bachelor's degree earned more than twice as much as those without a high school diploma or its equivalent in 2009 . . , 50 percent more than young adult high school completers, and 25 percent more than young adults with an associate's degree.").

46 BAUM ET AL., supra note 30, at 7 (comparing the earnings of high school graduates to those of college graduates and concluding that at about the age of 33 "higher earnings compensate ... for four years out of the labor force [and the] average tuition and fee payments at a public four-year university funded fully by student loans at $6.8 \%$ interest."); $c f$. $i d$. ("The earnings of associate degree recipients lead to a crossover at about the same age - after more years of work despite the lower tuition payments - because of the smaller earnings premium.").

${ }^{47}$ Jacob \& Wilder, supra note 21 , at 1.

${ }^{48}$ David Autor, Ctr. For Am. Progress, The Polarization OF Job OpPortunities in THE U.S. LABOR MARKET: IMPLICATIONS FOR EMPLOYMENT AND EARNINGS 5 (2010), available at http://www.americanprogress.org/issues/2010/04/pdf/job_polarization.pdf (“In 1963 , the hourly wage of the typical college graduate was approximately 1.5 times the hourly wage of the typical high school graduate. By 2009, this ratio stood at 1.95 . The entirety of this 45 percentage point rise occurred after 1980. In fact, the college-to-highschool earnings ratio declined by 10 percentage points in the 1970s.").

49 See, e.g., BAUM ET AL., supra note 30, at 17. 
The increased education premium is the result of both an increase in the inflation-adjusted earnings of college degree holders and a decrease in the earnings of high school educated workers. ${ }^{50}$ In fact, the decline in wages for those with just a high school diploma is described as a "major proximate cause" of the increased premium. ${ }^{51}$ But the larger cause of the trend is simple supply and demand. The last thirty years or so have seen a decrease in the relative supply of college-educated workers. ${ }^{52}$ As the economy has demanded more highly skilled, or college-educated, workers and the relative number of such individuals entering the workforce has declined, ${ }^{53}$ employers have been willing to pay more for those workers. ${ }^{54}$

\section{B. Economic Trends}

The modern economy is heavily tilted in favor of college-educated workers. Technological advancements and foreign outsourcing have led to a polarization or "hollowing out" of job opportunities in the U.S. ${ }^{55}$ The salient characteristics of this trend are an accumulation of job growth at the extremes of the spectrum and a diminishment of "middle-wage, middleskill" jobs. ${ }^{56}$ For example, job growth in high-skill fields ${ }^{57}$ has been strong during the last few decades; even during the "Great Recession," 58

${ }^{50}$ See AUTOR, supra note 48, at 26.

${ }^{51} \mathrm{Id}$. ("[M]ajor proximate cause of the growing college/high school earnings gap is not steeply rising college wages but rapidly declining wages for the less educated-especially less-educated males.").

${ }^{52}$ See id. at 1 ("[S]ince the late 1970 s and early 1980 s, the rise in U.S. education levels has not kept up with the rising demand for skilled workers, and the slowdown in educational attainment has been particularly severe for males. The result has been a sharp rise in the inequality of wages.").

${ }^{53}$ Id. at 25 ("[T] he skill demands of the U.S. economy did not stand still over the course of these decades even as college completion rates slowed. Consequently, college graduates are increasingly scarce relative to the set of jobs seeking them.").

${ }^{54} I d$. at 6 ("One important proximate cause for the rising relative earnings of college graduates is the slowdown in the rate of entry of new college graduates into the U.S. labor market starting in the early 1980 s.").

${ }^{55} I d$. at 2.

${ }^{56} \mathrm{Id}$. at 1 ; see also id. at 1610. (describing middle-wage, middle-skill jobs as "Sales, office/admin, production, and operators").

${ }^{57}$ Examples of high-skill jobs are "[m] anagerial, professional, and technical occupations." See id. at 10 .

${ }^{58}$ The term "Great Recession" is a popular reference to the recession that began in December 2007 and ended in June 2009. See, e.g., Neil Irwin, It's Official: The Great

Recession Ended Last Summer, WASH. Post, Sept. 20, 2010, http://voices.washingtonpost.com/politicalconomy/2010/09/its_official the great_recessi.html. 
opportunities in this sector remained stable. ${ }^{59}$ Similarly, the low-skilled job sector $^{60}$ survived the recession with no net job losses. ${ }^{61}$ On the other hand, middle-skill white-collar jobs declined by $8 \%$ and middle-skill blue-collar jobs fell by $16 \%$ between 2007 and 2009. ${ }^{62}$ Based on projections, job growth will be strongest in the high-skill, professional sector, followed by the low-skill, service sector. ${ }^{63}$ These trends demonstrate that the bulk of the well-paying job growth will be in fields that require highly educated workers who can think, adapt, and thrive in work environments increasingly dominated by technology. ${ }^{64}$ Middle-skill jobs that historically have required less than a bachelor's degree will be increasingly replaced by machines or outsourced to lower-cost workers in other countries. ${ }^{65}$

The trend away from less-educated workers has already begun in earnest. In 1973, workers with less than a college degree made up about $72 \%$ of the workforce; by 2007 , that proportion had fallen to just $41 \%{ }^{66}$ The actual numbers associated with these trends highlight the shift in even starker terms. Between 1970 and 2007, the number of workers in the U.S. increased by 63 million to a total of 154 million. ${ }^{67}$ However, even with this $70 \%$ increase, the total number of jobs for workers with less than a college degree fell by two million. ${ }^{68}$ Put differently, college educated workers netted 65 million new jobs over this 27 -year period, which accounted for

${ }^{59}$ AUTOR, supra note 48, at 8 ("Employment growth in these high-skill occupations was robust throughout the past three decades. Even in the current recession, these occupations experienced almost no decline in employment.").

${ }^{60}$ Examples of low-skill jobs are "[“"p]rotective service, food prep, janitorial/cleaning, personal care/services". See id. at 16.

${ }^{61} I d$. at 4.

${ }^{62} I d$.

${ }^{63}$ Id. at 12 ("The BLS forecasts that employment in service occupations will increase by 4.1 million, or 14 percent, between 2008 and 2018. The only major occupational category with greater projected growth is professional occupations, which are predicted to add 5.2 million jobs, or 17 percent.").

${ }^{64} I d$. at 23 ("The secularly rising demand for literate, numerate, and analytically capable workers stems from the changing job requirements of a rapidly technologically advancing economy.").

${ }^{65} I d$. at 2 ("The key contributors to job polarization are the automation of routine work and, to a smaller extent, the international integration of labor markets through trade and, more recently, offshoring.").

${ }^{66}$ Harvard Graduate SCH. Of Educ., Pathways to Prosperity Project: MeEting THE CHALlENGE OF PREPARING YOUNG AMERICANS FOR THE 21ST CENTURY 2 (2011) [hereinafter PATHWAYS TO PROSPERITY], http://www.gse.harvard.edu/news_events/features/2011/Pathways_to_Prosperity_Feb2011. ${ }^{67}$ Id.

${ }^{68} \mathrm{Id}$.; see also id. ("[O]ver the past third of a century, all of the net job growth in American has been generated by positions that require at least some post-secondary education."). 
$42 \%$ of all the jobs in $2007 .{ }^{69}$ Add to that number the almost 26 million jobs that were already filled by college educated workers, and the extent of the tilt in their favor becomes more evident. Moreover, economists project that of the 47 million jobs to be created between 2008 and 2018, collegeeducated workers will fill almost two-thirds of them. ${ }^{70}$ This trend will push the overall percentage of workers with no college experience below $40 \%{ }^{71}$

\section{Employment Trends}

Unsurprisingly, given job market trends, college-educated workers are more likely to be employed. In fact, education has been called "a pretty good insurance policy for workers during the Great Recession." 72 According to 2012 BLS statistics, the unemployment rate fell as education level increased. ${ }^{73}$ The rate for individuals with bachelor's degrees was $4.9 \%$, while the rate for individuals with high school diplomas was $9.4 \%{ }^{74}$ At opposite ends of the paradigm were individuals with doctoral degrees and those with less than high school diplomas-the latter having an unemployment rate almost six times higher than the former. ${ }^{75}$ Even when assessing the employment-to-population ratio, a broader measure of employment ${ }^{76}$ it is clear that college-educated individuals fare much better in the job market. In 2009, 82.5\% of all college-educated individuals were employed, compared to only $67.253 \%$ of high school educated individuals. ${ }^{77}$ During the most recent recession, the employment-to-

${ }^{69}$ Calculations by author. Id.

${ }^{70} \mathrm{Id}$.

${ }^{71}$ Calculations by author. Id.

72 Alan Berube, Brookings Inst., DegreEes of Separation: Education, EMPLOYMENT, AND THE GREAT RECESSION IN METROPOLITAN AMERICA 1 (2010), available at http://www.brookings.edu/ /media/Files/rc/papers/2010/1105_metro_america_berube/110 5 metro_america_education_berube.pdf.

${ }^{73}$ The unemployment rates for individuals with associate's degrees or higher were lower than the $7.6 \%$ overall rate. Individuals with lower levels of education had rates higher than the overall rate. BUREAU OF LAB. STAT., supra note 31.

${ }^{74} \mathrm{Id}$.

${ }^{75} \mathrm{Id}$. (listing the unemployment rates for individuals with doctoral degrees and those with less than a high school diploma as $2.5 \%$ and $14.1 \%$ respectively).

${ }^{76}$ The employment-to-population ratio is calculated using the employment status of all non-institutionalized individuals of working-age (16 and up). The unemployment rate is calculated using the employment status of working-age individuals, but only if they are employed or actively looking for employment. As such, the pool of individuals accounted for in the employment-to-population ratio is larger. See generally BUREAU OF LABOR STATISTICS, BLS INFORMATION, GLOSSARY, http://www.bls.gov/bls/glossary.htm.

${ }^{77}$ BERUBE, supra note 72 , at 3 . 
population ratio for individuals without a bachelor's degree fell at a rate more than four times that of individuals with the degree. ${ }^{78}$

The benefits of education on employment transcend race and age. Blacks, whites, and Hispanics all see greater odds of employment with higher education. ${ }^{79}$ For blacks, the employment gap between bachelor's degree-holders and those with only a high school diploma was almost seven percent; among whites and Hispanics, it was about 5\%. ${ }^{80}$ Among individuals aged 25-30, an associate's degree serves as an educational line of demarcation, with individuals at that level and above experiencing significantly better job prospects than those below. ${ }^{81}$ Interestingly, the benefits of education on employment do not just flow in the direction of the educated. Among the twenty most educated metropolitan areas, sixteen experienced below-average declines in employment, ${ }^{82}$ and these favorable conditions seemed to protect less educated workers from some of the unfavorable trends experienced by similar workers elsewhere. ${ }^{83}$ In other words, high levels of educational attainment foster healthy job markets that benefit even the less educated in those areas.

As part of a total compensation package, college educated workers tend to receive better fringe benefits than their less educated peers. Access to employer-sponsored pension plans tends to be tied to education level, ${ }^{84}$ as does employer-sponsored health care coverage. ${ }^{85}$ College educated

${ }^{78} I d$. ("The employment-to population ratio dropped by more than 2 percentage points from 2007 to 2009 for working-age adults without a bachelor's degree, but fell by only half a percentage point for college-educated individuals.").

${ }^{79}$ BAUM ET AL., supra note 30, at 21.

${ }^{80}$ Id.

${ }^{81}$ PATHWAYS TO PROSPERITY, supra note 66, at 5 ("Among all groups, young adults—aged 25 to 30 - who have earned at least an associate's degree, are significantly more likely to be employed than those who have a high school degree or less.").

${ }^{82}$ BERUBE, supra note 72, at 1 ("Among the 20 metro areas with the highest rates of bachelor's degree attainment, only four registered declines in their overall employment-topopulation ratio from 2007 to 2009 that exceeded the national average.").

${ }^{83}$ Id. ("[E]mployment for workers without a high school diploma was also less impacted in these highly educated metro areas than in other markets.").

${ }^{84}$ BAUM ET AL., supra note 30, at 23 ("[Seventy percent] of four-year college graduates were offered pension plans by their employers in 2008. Employer-provided pension plans were available to $65 \%$ of associate degree recipients, $61 \%$ of workers with some college but not degree, $55 \%$ of high school graduates, and only $30 \%$ of those who did not complete high school."); see also id. ("Among those to whom these plans are available, participation rates are higher for individuals with higher education levels.").

${ }^{85} \mathrm{Id}$. at 24 ("In 2008, 68\% of four-year college graduates working at least half-time in the private sector were covered by employer-provided health insurance. Only 50\% of high school graduates had this benefit."); see also id. ("The gap between health care coverage for high school graduates and four-year college graduates grew from 10 percentage points 
workers tend to be employed in more prestigious jobs ${ }^{86}$ and report having higher job satisfaction. ${ }^{87}$ Better work lives seem to contribute to better personal lives. Educated individuals are more likely to engage in leisure time activities, ${ }^{88}$ including volunteer work and other civic activities. ${ }^{89}$ This trend may be due to the better employment compensation and the greater autonomy afforded college educated workers. ${ }^{90}$ Many researchers have found a positive correlation between education and healthy lifestyle choices. $^{91}$ Educated workers are less likely to smoke ${ }^{92}$ or be obese. ${ }^{93}$ Additionally, education has been tied to better parenting practices and outcomes. The children of educated parents tend to be healthier, ${ }^{94}$ and they demonstrate higher cognitive ability ${ }^{95}$ than children of less educated parents. The benefits of having educated parents persist throughout the life of the child, with better employment outcomes as an adult being a common manifestation. ${ }^{96}$ And if all those benefits were not enough, some researchers have concluded that education actually makes an individual more attractive. ${ }^{97}$

in 1979 to 14 percentage points in 1988,17 percentage points in 1998 , and 18 percentage points in 2008.").

${ }^{86}$ Oreopoulos \& Salvanes, supra note 35 , at 8 (providing results of an occupational prestige study).

${ }^{87}$ BAUM ET AL., supra note 30, at 19 ("In 2008, about 58\% of college graduates and individuals with some college education or an associate degree reported being very satisfied with their jobs, while $50 \%$ of high school graduates and $40 \%$ of individuals without a high school diploma reported being very satisfied.").

${ }^{88} \mathrm{Id}$. at 28.

${ }^{89}$ Id. at 32. ("Both the percentage of people who donate their time to organizations and the number of hours people spend in volunteer activities are higher among individuals with higher levels of education."); see also id. at 33 ("In every age group, adults with higher levels of education are more likely to vote than those with lower levels of education.").

${ }^{90}$ See generally Oreopoulos \& Salvanes, supra note 35, at 6.

${ }^{91} \mathrm{Id}$. at 10 ("Many studies find a strong positive correlation between schooling and multiple measures of health outcomes, healthy habits, and healthy activities, with this correlation remaining large after conditioning on income.").

${ }^{92}$ BAUM ET AL., supra note 30, at 27.

${ }^{93}$ Id. at 29.

${ }^{94}$ See, e.g., id. at 30.

${ }^{95} \mathrm{Id}$. at 10.

${ }^{96}$ Oreopoulos \& Salvanes, supra note 35, at 12 ("For couples with children, parental schooling strongly relates to children's development and social-economic success throughout life. Health, social integration, test scores, and labor market outcomes all correlate positively with both mother and father's attainment.").

${ }^{97} I d$. at 11 (reasoning that "[m]en and women with more earnings potential or with more prestigious jobs become more appealing in a competitive marriage market"). 


\section{Societal Benefits}

This discussion would be incomplete without a mention of the societal benefits of education. Because educated individuals tend to make more money, they also tend to pay more taxes. Typically, a college educated worker will pay about $80 \%$ more in taxes than a high school educated worker. ${ }^{98}$ Higher education is also tied to less reliance on public assistance programs. ${ }^{99}$ In $2008,8 \%$ of high school educated adults aged 25 and older lived in households receiving food stamps, compared to $1 \%$ of adults with bachelor's degrees. ${ }^{100}$ And because college educated individuals commit less crime, society saves on incarceration costs. ${ }^{101}$ When the benefits of education are added up, the grand total is immense. The societal savings from an individual completing a college degree, as opposed to only earning a high school diploma, "range from $\$ 32,600$ for white women to $\$ 108,700$ for black men."102 So, does education pay? Indeed, it does.

\section{EDUCATION AS A RISKY INVESTMENT}

The payoff from education has cultivated an investment mindset among students. ${ }^{103}$ A recent study conducted by Gallup found that eightyfour percent of surveyed students strongly agreed with the statement: College is an investment in my future. ${ }^{104}$ Seventy-four percent strongly agreed that "having a college degree is more important now than it used to

${ }^{98}$ BAUM, ET AL., supra note 30, at 10.

${ }^{99}$ Id. ("Spending on social support programs such as unemployment compensation, food stamps, and Medicaid is much lower for individuals with higher levels of education.").

${ }^{100}$ Oreopoulos \& Salvanes, supra note 35 , at 8.

${ }^{101}$ BAUM, ET AL., supra note 30, at 4.

102 These figures were calculated by estimating the reductions in public expenditures associated with social programs and incarceration. Id. at 22.

${ }^{103}$ See, e.g., CONG. Budget OfFICE, The CONG. Of THE U.S., A CBO PAPER: Private AND Public Contributions to FinANCING COLlEge EduCATION 4 (2004) [hereinafter CBO PAPER], http://www.cbo.gov/ftpdocs/49xx/doc4984/01-23-Education.pdf.

${ }^{104}$ The survey asked respondents to indicate their level of agreement with a particular statement using a five-point scale, where a ' 5 ' indicated strong agreement and a ' 1 ' indicated strong disagreement. SALLIE MAE \& GALLUP, HOW AMERICA PAYS FOR College: SAllie MAE’s NAT’L Study of College Students AND PARENTS 50 (2010) [hereinafter GALLUP], https://www1.salliemae.com/NR/rdonlyres/D5D78A1C-BBB84D97-AE9B-

7EC35558AD5F/13390/SLMGallupReportHowAmericaPaysforCollege81010FINAL2.pdf. 
be."105 And even with increased costs of attendance, more than half of students strongly agreed both that college is worth the cost and that they were willing to stretch themselves financially to attend the best college possible. ${ }^{106}$ This desire to attend college and willingness to pay for it are reflections of the investment mindset that has spurred widespread participation in higher education. But, like all investments, educational investments are risky; some would say very risky. ${ }^{107}$

\section{A. Salary Trends}

For starters, speculating on future trends is always a risky endeavor, particularly when information is limited and options are numerous. The old investment adage "past performance does not necessarily predict future results" applies squarely to educational investments. While higher education seems increasingly obligatory in the workforce, the relative payoff seems to be leveling off, if not waning. Data compiled by the College Board showed that between 1998 and 2008, median salary increases for workers aged 25-34 with bachelor's degrees barely exceeded inflation. ${ }^{108}$ For younger workers with associate's degrees or some college experience, their salaries trailed inflation. ${ }^{109}$ So while workers with college experience fared better than other workers, ${ }^{110}$ the college investment looks surprisingly less favorable than the respondents to the Gallup survey would probably assume.

Ironically, one of the most compelling illustrations of the risks associated with investments in higher education is the most cited justification for incurring those risks: salary differentials. As discussed earlier, higher levels of education are associated with higher income. But the "Education pays" mantra largely ignores the variable nature of educational outcomes. Just because the median salary for bachelor's degree holders is higher than that of individuals with only high school diplomas does not mean that every bachelor degree holder makes more money than

\footnotetext{
105 Id. at 51 .

${ }^{106} \mathrm{Id}$.; see also id. at 52 (indicating that more than $60 \%$ of respondents from the lowest income households strongly agreed with these statements).

${ }^{107}$ LONG, supra note 16, at 1 (citing high costs and low completion rates in describing "the college investment" as a "high-risk proposition").

${ }^{108}$ BAUM, ET AL., supra note 30, at 16.

${ }^{109} \mathrm{Id}$.

${ }^{110} I d$. (emphasizing that the decline in wages for younger workers with associate's degrees or some college experience were not as steep as the declines for workers with only high school diplomas).
} 
every person with just a high school diploma. ${ }^{111}$ For example, about $20 \%$ of male bachelor's degree holders earn less than the median salary for high school graduates. ${ }^{112}$

Among women, $16 \%$ of bachelor's degree holders earned less than the median high school graduate salary. ${ }^{113}$ Another study found that more than a quarter of individuals possessing a post-secondary certificate or license earned more than the median bachelor's degree salary. ${ }^{114}$ These are not trivial exceptions. According to Census data, 60 million adults aged 25 and over possess bachelor's degrees. ${ }^{115}$ So these exceptions represent millions of individuals whose education investments are not paying off to the extent they likely expected.

A deeper review of the salary differential data reveals another important factor that often goes ignored: the publicized premium on higher education is often inflated. As mentioned earlier, one reason for the increased education premium over the last three decades was an increase in the inflation-adjusted earnings of college graduates. ${ }^{116}$ Cursory consideration of this trend might lead one to conclude that recipients of all college degrees enjoyed the same, or a similar, premium. However, most of the increase was experienced by workers with college degrees beyond the baccalaureate level. ${ }^{117}$ For example, between 1979 and 2007, the inflationadjusted earnings for men with bachelor's degrees increased 10\%; but the wages for men with graduate or professional degrees increased a much more robust $26 \% .{ }^{118}$ For women, the inflation-adjusted earnings for bachelor's degree and graduate or professional degree holders increased

${ }^{111}$ See, e.g., SANDy Baum \& SaUl Schwartz, College Board, How Much Debt Is Too Much? DEFInING BenchMARKS For MANAGEABLE STUdENT DEBT 7 (2006), available at http://professionals.collegeboard.com/profdownload/pdf/06-0869.DebtPpr060420.pdf.

${ }^{112}$ BAUM ET AL., supra note 30, at 7; see also id. (stating that $14 \%$ of males with only a high school diploma earned as much or more than the median salary for bachelor's degree holders).

${ }^{113}$ BAUM ET AL., supra note 30, at 15-16 (stating that 13\% of females with only a high school diploma earned as much or more than the median salary for bachelor's degree holders).

${ }^{114}$ PATHWAYS TO PROSPERITY, supra note 66 , at 3.

${ }^{115}$ U.S. Census Bureau, More Working Women Than Men Have College Degrees, CEnSUs BuREAu RePORTS (Apr. 26, 2011), http://www.census.gov/newsroom/releases/archives/education/cb11-72.html.

${ }^{116}$ A decline in the earnings of workers with only a high school diploma was the other reason. AUTOR, supra note 48, at 26.

${ }^{117} I d$. ("[A] sizable share of the increase in wages for college-educated workers relative to noncollege-educated workers since 1980 is explained by rising wages for workers with postbaccalaureate degrees.").

${ }^{118} I d$. 
$29 \%$ and $37 \%$ respectively. ${ }^{119}$ Combining these statistics, as is often done, likely overstates the payoff from earning a bachelor's degree-and as a result understates the investment risks.

\section{B. Economic Trends}

There is also concern that economic trends may be threatening jobs of college educated workers in a manner previously experienced by workers in manufacturing fields that did not require much education beyond high school. Nobel Laureate economist, Paul Krugman, states, "Many of the high-wage occupations that grew rapidly in the 1990s have seen much slower growth recently, even as growth in low-wage employment has accelerated." 120 The occupations to which Krugman is referring are among those that require higher education, and his conclusion acknowledges research showing that jobs in high-skill fields have become increasingly "tradable", "offshoreable", or susceptible to automation. ${ }^{121}$ One surprising finding is that jobs requiring higher levels of education might actually be more susceptible to offshoring than those requiring only low-levels. ${ }^{122}$

The prevailing view seems to be that it is the nature of a job, not the skill-level or education required, that determines its chances of being lost to foreign workers or to technology. If the service can be "delivered [to its end user] electronically over long distances with little or no degradation in quality", it is offshoreable (or tradable). ${ }^{123}$ If the job is sufficiently "rulebased," it can be automated. ${ }^{124}$ And these jobs are found across the skill

${ }^{119}$ Id. at 27.

${ }^{120}$ Paul Krugman, Degrees and Dollars, N.Y. TIMES, Mar. 7, 2011, at A21, available at http://www.nytimes.com/2011/03/07/opinion/07krugman.html.

121 "Tradable" and "offshoreable" are largely synonymous concepts theorized by economists seeking to describe the extent to which an industry and the jobs therein are at risk of being lost to cheaper workforces in other countries. J. Bradford Jensen \& Lori G. Kletzer, Tradable Services: Understanding the Scope and Impact of Services Outsourcing, 1-22 (Inst. for Int'l Econ. Working Paper No. 05-9, 2005), available at http://www.piie.com/publications/wp/wp05-9.pdf. See, also, Alan S. Blinder, How Many U.S. Jobs Might Be Offshoreable?, 1-44 (Ctr. for Econ. Pol'y Studies, Working Paper No. 142, 2007), available at http://www.princeton.edu/ ceps/workingpapers/142blinder.pdf.

${ }^{122}$ Blinder, supra note 121, at 33 (finding a weak direct correlation between "offshoreability" of occupations and the level of higher educational attainment they require).

${ }^{123} I d$. at 2.

${ }^{124}$ David H. Autor, Frank Levy \& Richard Murnane, The Skill Content of Recent Technological Change: An Empirical Exploration 1-45 (Nat'l Bureau of Econ. Research, Working Paper No. 8337, 2000), available at http://web.mit.edu/flevy/www/skillcontent.pdf. 
and education spectra. ${ }^{125}$ In fact, employers may have an enhanced financial incentive to automate or ship high-paying jobs overseas. ${ }^{126}$ The implications of these trends on the educational investment are captured by Krugman: "It's no longer true that having a college degree guarantees that you'll get a good job, and it's becoming less true with each passing decade." 127 It should be noted that Krugman is not arguing against education; he is arguing that education no longer provides a sure route to the middle-class.

When assessing the wisdom of any investment, it is important that costs and potential payoff be considered together. Researchers have estimated that the "break even" point for bachelor's degree holders occurs at about the age of $33 .{ }^{128}$ Based on this estimate, the typical worker with a bachelor's degree has ample time to realize a profit on his educational investment. ${ }^{129}$ However, a few trends render this estimate less reflective of today's reality. Many students are attending college later in life, ${ }^{130}$ thereby reducing the amount of time they are able to profit from their educational investment. Also, many students are taking longer to complete their studies, ${ }^{131}$ a proverbial "double-whammy" that not only reduces the amount of time they are able to profit, but also increases the amount of time necessary to profit. ${ }^{132}$ In addition, education costs have continued to greatly

${ }^{125}$ Blinder, supra note 121 , at 32.

${ }^{126}$ Martin Ford, Can a Computer Do a Lawyer's Job?, The AtLantic, Feb. 15 2011, available at $\mathrm{http} / / / \mathrm{www}$.theatlantic.com/business/archive/2011/02/can-a-computer-do-alawyers-job/71238/.

${ }^{127}$ Krugman, supra note 120. See also id. (arguing that strengthening labor unions and providing universal health care are more effective means of fostering prosperity than education).

${ }^{128}$ BAUM ET AL., supra note 30, at 7.

${ }^{129}$ The educational investment (i.e. costs) consists not only of direct expenses, such as tuition, but also opportunity costs, mainly in the form of lost income. See, e.g., id. at 4.

${ }^{130}$ See, e.g., U.S. DEP'T OF LABOR, ADULT LEARNERS IN HIGHER EDUCATION: BARRIERS TO SUCCESS AND STRATEGIES TO IMPROVE RESULTS 3 (2007),

http://wdr.doleta.gov/research/FullText_Documents/Adult\%20Learners\%20in\%20Higher\% 20Education1.pdf.

131 JOHN BRIDGELAND ET AL., CIVIC ENTERPRISES, ACROSS THE GREAT DIVIDE 13 (2011), available at http://www.civicenterprises.net/reports/across_the_great_divide.pdf ("[F]rom 1968 to 2007 the college completion rate remained relatively constant while time- todegree increased.").

${ }^{132}$ Increased time in school is associated with higher education costs. See, e.g., Nate Johnson, Complete College America, Three Policies to Reduce Time to Degree 1 (2011), available at

http://www.completecollege.org/docs/Three\%20Policies\%20to\%20Reduce\%20Time\%20to \%20Degree\%20-\%20Nate\%20Johnson.pdf. But cf., BAUM ET AL., supra note 30, at 13 (acknowledging that $43-53 \%$ of students work while enrolled and these earnings reduce 
outpace inflation, ${ }^{133}$ further amplifying salary stagnation and extending the break-even point.

But even with these trends, most researchers still agree that higher levels of education remain superior to lower levels in terms of investment payoff - at least generally. So instead of "Education pays", a more appropriate tagline might be "Education can pay", based largely on the type of degree earned and the amount of time and money expended.

Irrespective of the risks, college participation continues to increase and, along with increased education costs, has hastened the prominence of another form of risk into the educational investment equation: student loans.

\section{STUDENT LOANS AS "ENLIGHTENED SOCIAL POLICY”}

Education access has been an "enlightened social policy"134 of the federal government for more than a half century. ${ }^{135}$ The federal government's role in student financial aid was instigated in large part by race-based and class-based college enrollment gaps. ${ }^{136}$ Policymakers reasoned that financial aid would be an effective means of spurring educational investments by members of underrepresented groups. The idea of public investments in what is essentially a private (or individual) endeavor has been justified based on the public benefits of an educated populace and the public burdens of under-investments in education. ${ }^{137}$ The

education costs by reducing opportunity costs).

${ }^{133}$ See, e.g., FEDERAL STUDENT AID, U.S. DEP'T OF EDUC., FEDERAL STUDENT Aid: STRATEGIC PLAN FY 2011-15 iii (2010), http://federalstudentaid.ed.gov/static/gw/docs/FiveYearPlan_2011.pdf [hereinafter FSA STRATEGIC PLAN] ("The average cost of postsecondary education has been rising far faster than inflation, increasing the financial pressures on students and their families.").

${ }^{134}$ The Brunner court termed the federal government's efforts to make student loans accessible to students who would not qualify for loans in the private market "enlightened social policy". The policy objective was education access. In re Brunner, 46 B.R. at 756

${ }^{135}$ The Higher Education Act of 1965 is said to have represented the first sign of a federal commitment to access in higher education. See, e.g., Lawrence E. Gladieux \& Jacqueline E. King, The Federal Government and Higher Education, in AMERICAN HIGHER EDUATION IN THE TWENTY-FIRST CENTURY 151 (Philip G. Altbach et al. eds,,1999).

${ }^{136}$ See, e.g., SANDRA R. BAUM, INSTITUTE FOR RESEARCH ON POVERTY, FINANCIAL AIS TO LOW-INCOME COLLEGE STUDENTS: ITS HISTORY AND PROSPECTS 5 (1987), available at http://www.eric.ed.gov/PDFS/ED377265.pdf ("The changed social attitude toward poverty and society's responsibility for economic conditions had created concern over the imbalance in college attendance by race and family income.").

${ }^{137}$ CONG, Budget OfFice, The CONG. OF THE U.S., A CBO Study: Costs AND Policy OPTIONS FOR FEDERAL STUDENT LOAN PROGRAMS 13 (2010), availabl at 
titans of the federal student aid policy are Pell grants and student loans.

\section{A. Pell Grant}

The Pell Grant Program was created by legislation in 1972 and is the hallmark higher education need-based grant program. ${ }^{138}$ The program is behemoth, with more than nine million recipients splitting grants totaling $\$ 30$ billion during the 2010-2011 school year. ${ }^{139}$ Very generally, Pell eligibility is determined by the difference between a student's cost of attendance and her Expected Family Contribution (EFC). ${ }^{140}$ Any difference between the cost of attendance and EFC is covered by a Pell grant up to the Congressionally-stipulated maximum for that school year $(\$ 5,550$ for 20112012). ${ }^{141}$ For example, a student with a cost of attendance equaling or exceeding the maximum Pell grant and an EFC of $\$ 0$ will receive the maximum award. Students do not have to repay these grants, except under very limited circumstances. ${ }^{142}$ The rapid growth of the program ${ }^{143}$ has become a source of concern, if not consternation. ${ }^{144}$ Ironically, even though

http://www.cbo.gov/ftpdocs/110xx/doc11043/03-25-StudentLoans.pdf [hereinafter CBO Study] ("The benefits of subsidizing education may also outweigh the costs when education produces benefits for society in addition to the private benefits enjoyed by the student. Students may fail to take those social benefits into account when making choices about their education, which provides a case for government subsidization.").

${ }^{138}$ See, e.g., ThOMAS J. KANE, THE PRICE OF ADMISSION: RETHINKING How AMERICANS PAY FOR COLLEGE (1999).

${ }^{139}$ U.S. DeP'T OF EDUC., 2009-2010 FEDERAL PELL GRANT PROGRAM END-OF-YEAR REPORT 1 (2011), available at http://www2.ed.gov/finaid/prof/resources/data/pell-200910/pell-eoy-09-10.pdf.

${ }^{140}$ The Expected Family Contribution (EFC) is a formula computed using information provided by a student in her Free Application for Federal Student Aid (FAFSA). The EFC is used to compute eligibility for various forms of student aid. FEDERAL STUDENT AID, U.S. DEP'T OF EDUC., YOUR FEDERAL STUDENT LOANS: LEARN THE BASICS AND MANAGE YOUR DEBT 39 (2010) [hereinafter MANAGE YOUR DEBT], available at http://studentaid.ed.gov/students/attachments/siteresources/11-12YFSL.pdf. See generally, U.S. DEP'T OF EdUC., FEDERAL PELl GRANTS, FisCAL YEAR 2011 BUdGET REQUEST P-3 (2010) [hereinafter PELl BUdGet REQUEST], available at http://www2.ed.gov/about/overview/budget/budget11/justifications/p-pell.pdf (explaining how EFC is calculated).

${ }^{141}$ Pell Budget ReQuest, supra note 140, at p-3.

${ }^{142}$ A student may have to repay a Pell grant in some cases when she withdraws from school. MANAGE YOUR DEBT, supra note 140, at 4.

${ }^{143}$ In the last decade, Pell expenditures have increased from about $\$ 8$ billion to about $\$ 30$ billion. In the past three years alone, expenditures have doubled, with most of that increased coming over the last year. The number of grant recipients has increased $46 \%$ over the last three years. Pell Budget ReQuest, supra note 140, at Table 1.

${ }^{144}$ See, e.g., Richard Vedder, Pell-Mell, CHRON. HigHER EDUC., Mar. 17, 2011, available 
costs associated with the program continue to skyrocket, the "buying power" of the grants continues to decline. ${ }^{145}$

\section{B. Student Loans}

Federal student loans were first authorized in 1958 as part of the National Defense Education Act. ${ }^{146}$ The initial program was extremely limited compared to the system we have today. Roughly $\$ 300$ million was appropriated over four years for institutions to disburse as interestsubsidized loans to undergraduate students with financial need. ${ }^{147}$ During the 1980s, student loans became the centerpiece of federal student aid efforts. By 1985, student loans had grown to $50 \%$ of the federal aid students received. ${ }^{148}$ In the time period spanning 2006-2012, federal student loan volume more than doubled. ${ }^{149}$ The volume has increased almost $400 \%$ since $1999 .{ }^{150}$ Since 2006 , the number of students receiving federal student loans has almost doubled-now totaling more than 25 million. ${ }^{151}$ And unsurprisingly, total outstanding federal student loan debt

at http://chronicle.com/blogs/innovations/pell-mell/28873 (proposing various reforms to Pell program to reduce costs and increase "bang for our buck").

${ }^{145}$ The maximum Pell grant (\$5,550 for $2011-2012$ ) covers $32 \%$ of the in-state cost of attending a public, 4 -year college or university, down from $44 \%$ a decade earlier. The buying power at private, 4-year colleges and universities has fallen from 17\% in 1992 to $14 \%$ in 2012. COLLEGE BOARD TRENDS IN HIGHER EDUCATION: TRENDS IN STUDENT AID 2011 (2011) [hereinafter TRENDS IN STUDENT AID], available at http://trends.collegeboard.org/downloads/Student_Aid_2011.pdf.

${ }^{146}$ Statement of Alfred B. Fitt, General Counsel, Cong. Budget Office: Hearing Before the H. Subcomm. on Postsecondary Education, Comm. on Education and Labor 3 (1979) [hreinafter CBO Hearing], http://www.cbo.gov/ftpdocs/52xx/doc5223/doc20.pdf.

${ }^{147}$ The original law set the program length at 8 years. For every $\$ 9$ in loan funds received from the government, schools were required to add $\$ 1$. Interest was set at 3\%, essentially the "cost of money". Id.

${ }^{148}$ BAUM, supra note 136 , at 41.

${ }^{149}$ For FY2006, total new volume through the Federal Family Education Loan Program and the Federal Direct Student Loan Program was $\$ 58,864,000,000$. In FY2012, volume was \$124,318,000,000. U.S. DEP'T OF EDUC. STUDENT LOANS OVERVIEW: FISCAL YEAR 2012 Budget REQUEST S-13 (2012) [hereinafter FISCAL YEAR 2012 BudGET REQUEST], http://www2.ed.gov/about/overview/budget/budget12/justifications/s-loansoverview.pdf.

${ }^{150}$ For FY1999, new student loan volume was \$33,712,385,207. U.S. DEP’T OF EDUC., FEDERAL STUdENT FinANCIAL ASSISTANCE Programs - LOAN Volume UPdATES (10/29/10) [hereinafter LOAN VOLUME UPDATES], available at http://www2.ed.gov/finaid/prof/resources/data/opeloanvol.html (click on appropriate year for spreadsheet listing data).

${ }^{151}$ For FY2006, the total number of federal loan recipients was 13,667,000. For FY2012, recipients totaled 25,124,000. FISCAL YEAR 2012 BUDGET REQUEST, supra note 148, at S13. See, also, LOAN VOLUME UPDATES, supra note 149 (listing the number of FY1999 
has increased more than $540 \%$ since 2000 , now totaling $\$ 807$ billion. ${ }^{152}$

There are three types of federal student loans: Stafford, Direct PLUS, and Perkins. ${ }^{153}$ By far, the largest of the three is the Stafford loan program, accounting for $80 \%$ of new loan volume. ${ }^{154}$ Stafford loans come in two forms: subsidized and unsubsidized. ${ }^{155}$ The interest on subsidized loans is paid by the government while the student is enrolled in school at least half-time and for a six month "grace period" thereafter; interest accrues on unsubsidized loans from the point they are disbursed. ${ }^{156} \mathrm{~A}$ student can qualify for both forms of Stafford loans (up to applicable maximums), with the subsidized amount being based on financial need. ${ }^{157}$

Direct PLUS loans are available to graduate and professional school students and parents of dependent students. ${ }^{158}$ The purpose of PLUS loans is to account for the difference between a student's cost of attendance and any other aid the student has received, including scholarships, grants, and other loans. ${ }^{159}$ Interest accrues on PLUS loans from the point they are disbursed. ${ }^{160}$ In addition, borrowers must pass a nominal check of "adverse credit history". ${ }^{161}$ Perkins loan eligibility is based on financial need. The program is funded by a combination of federal and institutional funds; only about 1,800 of the 2,900 institutions eligible to receive federal financial aid funds participate. ${ }^{162}$

Most of these loans have to be repaid; however, the government subsidizes loans mainly by offering them at lower interest rates than are available in the private market and by tolling the accrual of interest for certain students. ${ }^{163}$ Most federal student loans are offered without regard to

federal loan recipients was $8,766,922$ ).

${ }^{152}$ CBO STUDY, supra note 137, at Summary (listing the outstanding debt as $\$ 149$ billion in 2000). See, also, FisCAL YEAR 2012 BUDGET REQUEST, supra note 149, at S-20, 21

(listing outstanding debt figures for FY 2012).

${ }^{153}$ MANAGE Your DeBT, supra note 140, at 5.

${ }^{154}$ CBO STUDY, supra note 137, at 1.

${ }^{155}$ MANAGE Your DeBT, supra note 140 , at 5.

${ }^{156} I d$.

${ }^{157} I d$.

${ }^{158} I d$.

${ }^{159} I d$.

${ }^{160} \mathrm{Id}$.

${ }^{161}$ Id. See generally, Federal Direct Parent Plus Loan Information, Office of Student Financial Aid, THE OHIO STATE UNIVERSITY, http://sfa.osu.edu/forms/award/plus.pdf (last visited May 12, 2012) (listing grounds for PLUS loan denial as loan delinquencies, "bankruptcy discharge, foreclosure, repossession, tax lien, wage-garnishment, or write-off of Title IV debt during the last 5 years").

${ }^{162}$ U.S. DeP'T OF EdUC., Federal Perkins LoAn Program (2009), http://www2.ed.gov/programs/fpl/index.html.

${ }^{163}$ See, e.g., CBO PAPER, supra note 103. 
credit rating. ${ }^{164}$ So the subsidies are greatest for individuals with bad credit, as private lenders would likely impose higher interest rates. ${ }^{165}$ Moreover, the subsidies serve the access goal mainly by providing a source of funds to many individuals who would not qualify for private loans at all. ${ }^{166}$

Even though federal student loans were introduced in a climate of "ideological and philosophical objections...to helping students by making debtors out of them", ${ }^{167}$ the programs' scope and size have been continually broadened, even against early Presidential objections. ${ }^{168}$ Today, with outstanding student loan debt expected to soon top \$1 trillion, surpassing credit card debt, ${ }^{169}$ popular discussion of student loans is often captured in ominous headlines warning of "bubbles" bursting and other financial mayhem. ${ }^{170}$ So it seems that the ideological and philosophical differences of yore are taking on new prominence as student loan debt reaches uncharted levels. But like all forms of debt, student loans are a reflection of larger trends, and the rise in student loan debt can be attributed to increased college participation and increased education costs. ${ }^{171}$

\section{Increased College Participation}

Higher education has experienced explosive growth over the last 40 years. Between 1970 and 2009, enrollment in degree-granting institutions more than doubled, from 7.4 million to 17.6 million. ${ }^{172}$ This growth is likely to continue, as projections indicate that 19.6 million students will be pursuing college degrees in 2020. ${ }^{173}$ Increases in college-going rates among

${ }^{164}$ See, e.g., MANAGE YOUR DEBT, supra note 140 , at 8.

${ }^{165}$ CBO STUDY, supra note 137, at 10 ("[T] he government furnishes a subsidy... whenever it accepts terms on the financing it provides that are more favorable than the terms that participants in private markets would demand to take on comparable obligations and risks.").

${ }^{166} \mathrm{Id}$. at 24 ("[S]ome evidence suggests that federal policy has been effective at easing [credit] constraints for most students.").

${ }^{167}$ Id. at 1.

${ }^{168}$ CBO Hearing, supra note 146, at 3 (remarking in 1979 that Congress continued to reauthorize and generously fund student loan programs over the objections of "every president since President Eisenhower").

${ }^{169}$ Tamar Levin, Burden of College Loans on Graduates Grows, N.Y. TIMES, Apr. 12, 2011, at A1, available at http:/www.nytimes.com/2011/04/12/education/12college.html?_r=4\&hp.

${ }^{170}$ See, e.g., Larry Doyle, Are Student Loans an Impending Bubb̄le? Is Higher Education a Scam?, BUSINESS INSIDER, May 2, 2011, available at http://www.businessinsider.com/arestudent-loans-an-impending-bubble-is-higher-education-a-scam-2011-5\#ixzz1NW0MVtet.

${ }^{171}$ See, e.g., Cво STUDY, supra note 137.

${ }^{172}$ AUD ET. AL.., supra note 45, at 34.

${ }^{173}$ Id . 
both "traditional" and "non-traditional" students have fueled the growth. ${ }^{174}$ In $2009,52 \%$ of $20-21$ year olds were enrolled in college, up from $32 \%$ in $1970 .{ }^{175}$ Similarly, $14 \%$ of individuals age $25-29$, a non-traditional age range, were enrolled in college in 2009, up from 8\% in 1970. ${ }^{176}$ Enrollment increases have been spread across all sectors of higher education. Between 2000 and 2009, undergraduate enrollments at public, private, and for-profit institutions increased $27 \%, 17 \%$ and $400 \%$ respectively. ${ }^{177}$ Postbaccalaureate enrollments have increased as well, rising from 1.6 million in 1983 to 2.9 million in $2009 .{ }^{178}$ All of these increases are projected to persist at various levels through $2020 .{ }^{179}$

\section{Increased College Costs}

College costs of attendance have been on a steady rise for over 30 years. The average published in-state tuition and fees for a 4-year public college or university was $\$ 8,244$ in 2011-2012 - an increase of $8 \%$ over the previous school year. ${ }^{180}$ Public out-of-state tuition and fees increased $6 \%$ in $2011-2012$, to $\$ 20,770{ }^{181}$ Tuition and fees at community colleges increased $9 \%$, to $\$ 2,963$. ${ }^{182}$ Private 4-year colleges and universities saw an increase of $4.5 \%$ in $2011-2012$, to $\$ 28,500{ }^{183}$ The average among forprofit institutions increased $3 \%$, to $\$ 14,487 .{ }^{184}$

The annual increases in college costs have outpaced inflation. The decade from 2000 to 2009 saw yearly increases in education costs of $6.5 \%$ per year at public 4-year institutions, $5.6 \%$ at private 4-year schools, and

\footnotetext{
${ }^{174}$ FSA STRATEGIC Plan, supra note 133, at 7 (defining traditional students as those who "go to college directly after high school" and non-traditional students as "those who are 25 years old and above").

${ }_{175}$ AUD ET. AL.. supra note 45, at 138.

${ }^{176} \mathrm{Id}$.

${ }^{177}$ Public enrollments increased from 10.5 to 13.4 million; private enrollments increased from 2.2 to 2.6 million; for-profit enrollments increased from 400,000 to 1.6 million. $I d$. at 34.

${ }^{178} I d$. at 36.

${ }^{179} \mathrm{Id}$. ("Fall enrollment in postbaccalaureate programs is projected to increase through 2020 to 3.4 million students.").

${ }^{180}$ College Board Advocacy \& Policy Center, Trends in College Pricing 2011 (2011) [hereinafter TRENDS IN COLLEGE PRICING], available at http://trends.collegeboard.org/downloads/College_Pricing_2011.pdf.

${ }^{181} I d$.

${ }^{182} I d$.

${ }^{183} \mathrm{Id}$.

${ }^{184} \mathrm{Id}$.
} 
$5.3 \%$ at community colleges. ${ }^{185}$ Since 2006 , costs at for-profit schools have increased $7.6 \%$ per year. Inflation during this period was about $2.5 \%$ per year. $^{186}$

The rise in educations costs is showing no signs of abating, with further increases projected through 2015. ${ }^{187}$ If these increases continue at the same rates, the costs of attending college in 2015 will be more than double the costs in 2000. ${ }^{188}$ It is important to point out that not all students pay the published tuition rate. After various forms of aid are applied, many, if not most, students pay much less. But even net prices are higher today than they were in $2000 .^{189}$

Increases in college costs have played out in the context of stagnant and declining wages. And while the cited reasons for the increases vary, ${ }^{190}$ the consensus seems to be that the increases are unsustainable. ${ }^{191}$ Families are already responding strongly to the increased costs. The Gallup survey found that $63 \%$ of families disqualified schools based on costs; this was $7 \%$ higher than the previous year. ${ }^{192}$ Additionally, tuition increases were the greatest worry among white, black and Hispanic parents. ${ }^{193}$ "Extreme" worry about the economics of attending college increased as income-level decreased. $^{194}$ This finding, while intuitive, is a little ironic, given that poorer students tend to pay lower net prices for college. The finding is also troubling, given that negative perceptions of costs can depress enrollments rates among groups that are already underrepresented in college. ${ }^{195}$

${ }^{185}$ FSA STRATEGIC PLAN, supra note 133, at 5. See generally, AUD ET. AL., supra note 45, at 132 (explaining that total cost of attendance "includes tuition and fees, books and materials, and an allowance for living expenses.").

${ }^{186} \mathrm{Id}$.

${ }^{187}$ Id. at 6.

${ }^{188} \mathrm{Id}$.

189 AUD ET. AL.. supra note 45, at 128 ("For low-income, middle-income and high-income families, the net price increased, respectively by $\$ 1,400, \$ 2,200$, and $\$ 3,600$.”).

190 Taylor, supra note 26, at 749 (explaining that declining state funding for higher education has prompted schools to raise revenue through tuition increases). See also, Dill, supra note 18, at 143 (citing theory that asserts increased competition among institutions for prestige has engendered tuition increases).

191 See, e.g., TRENDS IN COLLEGE PRICING, supra note 180, at 9.

192 GALLUP, supra note 104, at 43.

${ }^{193}$ Concern about tuition increases exceeded those related to things like joblessness and decreases in savings, investments, and home values. $I d$. at 54.

${ }^{194} I d$. ("More respondents from households with annual incomes of less than $\$ 35,000$ were extremely worried about all of the economic factors while many fewer families with incomes of $\$ 150,000$ or more reported being extremely worried.")

${ }^{195}$ See, e.g., BURDMAN, supra note 17. 


\section{E. Increased Loan Reliance}

Increases in student loan interest rates were the second biggest worry among white, black and Hispanic parents. ${ }^{196}$ The parents' concern makes sense, given the extent to which their children will likely rely on student loans to pay for college. The recession brought about a decline in the availability of non-federal college funding sources. ${ }^{197}$ This declination has coincided with a rise in student loan borrowing. During the 2008-2009 school year, $56 \%$ of full-time undergraduate students utilized students loans; ${ }^{198}$ this was up from $45 \%$ during $1999-2000 .{ }^{199}$ The average loan from all sources, including private loans, was $\$ 8,200$ in 2007-2008 compared to an inflation-adjusted $\$ 6,500$ in $1999-2000{ }^{200}$

\section{Degree Type}

Comparing graduates who received their degrees in 2008 to those who did so in 1996 illustrates a startling trend: bachelor's degree recipients who graduated in 2008 with debt borrowed $\$ 23,287$, compared to $\$ 17,075$ among 1996 graduates - a 36\% increase; those who graduated with associate's degrees with debt borrowed $\$ 13,321$ in 2008 , compared to $\$ 7,751$ in 1996 - a $72 \%$ increase; certificate program graduates with debt borrowed $\$ 11,427$ in 2008 , compared to $\$ 7,300$ in 1996 -a $57 \%$ increase. ${ }^{201}$ In addition, the percentage of graduates with more than $\$ 15,000$ in debt increased more than $50 \%$ between 1996 and $2008 .^{202}$ About $17 \%$ of all bachelor's degree graduates had debt of $\$ 30,500$ or

${ }^{196}$ GALLUP, supra note 104, at 53.

${ }^{197}$ Not only did the recession decrease family, institutional, and state funding sources, it also led to a decline in the availability of private student loans. The latter effect has led to increased reliance on federal student loans. Federal loans offer much more favorable repayment terms than private loans, including subsidized interest rates, multiple repayment options, hardship deferments and forbearances, and no credit check. See, e.g., ManaGe YOUR DEBT, supra note 140, at 6.

${ }^{198}$ AUD ET AL., supra note 45, at 132. See also, Program Integrity: Gainful Employment, 75 Fed. Reg. 142, at 101 (proposed July 26, 2010) (to be codified at 34 C.F.R. pt. 668) [hereinafter Program Integrity] (stating that at four-year institutions, more than half of fulltime students make use of student loans, compared to about $17 \%$ twenty years ago).

${ }^{199}$ AUD ET AL., supra note 45, at 126.

${ }^{200} I d$.

${ }^{201}$ RebeCCA HinZe-Fifer \& Richard Fry, Pew Research CEnTER, THE RISE OF COLlEGE STUDENT BorRowing 5 (2010), available at http://pewsocialtrends.org/files/2010/11/social-trends-2010-student-borrowing.pdf. ${ }^{202} I d$. at 8. 
more - a threshold that is considered "high-debt". 203

\section{Institution Type}

Borrowing rates vary among different types of institutions, but they have increased across all of them. ${ }^{204}$ Half of 2008 graduates of public colleges and universities had student loan debt, compared to $46 \%$ in 1996. ${ }^{205}$ Among private institution graduates, borrowing rates increased from $59 \%$ in 1996 to $72 \%$ in $2008 .^{206}$ The largest increase, however, was in the for-profit sector. Ninety-five percent of 2008 graduates borrowed money for school, compared to $77 \%$ in $1996 .{ }^{207}$ Debt loads increased across all institution types as well. Debt among graduates from public institutions who borrowed increased almost 29\%, from $\$ 15,599$ among 1996 graduates to $\$ 20,087$ among 2008 graduates. $^{208}$ Private school graduates saw their debt increase $41 \%, \$ 19,852$ in 1996 and $\$ 28,039$ in $2008{ }^{209}$ During a shorter timeframe, 2004-2008, graduates with debt from for-profit schools saw their debt increase about 10\%, from \$30,106 in 2004 to $\$ 33,046$ in $2008 .^{210}$

\section{Socioeconomic Level and Race}

Even though low-income students tend to pay lower net tuition, they rely on student loans more heavily than other students. The typical lowincome student relied on loans to pay about $18 \%$ of the total cost of attending college; middle-income and high income students relied on loans for $15 \%$ and $7 \%$ respectively. ${ }^{211}$ There is a racial component to these income-based borrowing trends, particularly as they relate to black students. Black students disproportionately come from low-income households, ${ }^{212}$

\footnotetext{
${ }^{203}$ SANDy Baum \& PATricia SteEle, College BoArd AdVOCACY AND Policy CENTER, WHO BORROWS MOST? BACHELOR's DEGREE RECIPIENTS WITH HIGH LEVELS OF STUDENT DEBT 10 (2010), available at http://www.collegeboard.com/prod_downloads/trends/trendswho-borrows-most-brief.pdf.

${ }^{204}$ AUD ET AL., supra note 45, at 128 ("When adjusted for inflation to 2009-10 dollars, the average amount borrowed by students at each of the six major combinations of institution level and control was higher in 2007-08 than in 1999-2000.”).

${ }^{205}$ HINZE-PIFER \& FRY, supra note 202, at 3.

${ }^{206} \mathrm{Id}$.

${ }^{207} \mathrm{Id}$.

${ }^{208}$ Id. at 8.

${ }^{209} \mathrm{Id}$.

${ }^{210} \mathrm{Id}$.

${ }^{211}$ GALLUP, supra note 104, at 18.

212 A. Mechele Dickerson, Race Matters in Bankruptcy Reform, 71 Mo. L. Rev. 919, 935
} 
and this trend contributes to disproportionately high debt levels. ${ }^{213}$ Income levels, however, do not fully explain the higher debt among black students $;^{214}$ institution choice plays a role as well. Seventeen percent of black students attend for-profit institutions, which is almost double the next highest proportion for other racial/ethnic groups. ${ }^{215}$ Students at for-profit schools have the highest borrowing rates and debt in higher education. ${ }^{216}$ Additionally, students at for-profit institutions are more likely to be classified as "independent" 217 for financial aid purposes, and thus able to borrow more money and accumulate more debt. ${ }^{218}$ Almost a quarter of 2008 graduates who were independent students are at or above the highdebt threshold of $\$ 30,500 .^{219}$ Based on enrollment and borrowing trends, black students likely make up a disproportionately high proportion of this group.

High student loan debt would not be a problem if all borrowers completed their academic or training programs and got jobs that paid sufficiently high wages. In fact, under that ideal scenario, the concept of "high debt" would not even exist. Alas, we do not live in Utopia, and there are many people facing high student loan debt, low (or no) wages, and unfulfilled college aspirations. When the latter takes the form of failure to complete an academic or training program, it becomes particularly crippling to realize a return on the educational investment. Failure to complete an academic program is a strong predictor of student loan default. ${ }^{220}$ And unfortunately, failure to complete is an all-too-common outcome in U.S. higher education.

(2006).

213 BAUM \& STEELE, supra note 203, at 6 ("High debt levels are more prevalent among black bachelor's degree recipients than among those from other racial/ethnic groups... Twenty-seven percent of 2007-08 black bachelor's degree recipients borrowed $\$ 30,500$ or more, compared to $16 \%$ of whites, $14 \%$ of Hispanics/Latinos, and $9 \%$ of Asians.").

${ }^{214} I d$.

${ }^{215}$ Other proportions are as follows: Hispanic: 10.1\%, American Indian/Alaska Native: 9.4\%, White: 7.4\%, Asian/Pacific Islander: 5.2\%. AUD ET AL., supra note 45, at 273. ${ }^{216}$ See, e.g., HINZE-PIFER \& FRY, supra note 201.

${ }^{217}$ According to federal student loan guidelines, an "independent student" is someone who is "at least 24 years old, married, a graduate or professional student, a veteran, a member of the armed forces, an orphan, a ward of the court, someone with legal dependents other than a spouse, an emancipated minor, or is homeless or at risk of homelessness." MANAGE YOUR DEBT, supra note 140, at 40.

${ }^{218}$ HINZE-PIFER \& FRY, supra note 201, at 9.

${ }^{219}$ BAUM \& STEELE, supra note 203, at 3.

${ }^{220}$ Program Integrity, supra note 198, at 102. 


\section{FAILURE TO COMPLETE AS INVESTMENT FAILURE}

Higher education failure is a serious problem. Long the envy of higher education in the world, the U.S. now has the highest failure rate among industrialized countries. ${ }^{221}$ Today, almost half of individuals who begin an academic or training program fail to complete. ${ }^{222}$ This trend is exemplified in how the U.S. compares to other countries in terms of educational attainment: Among individuals aged 55-64, the U.S. is first in higher education attainment; $4^{\text {th }}$ among 35-44 year olds; and $10^{\text {th }}$ among $25-34$ year olds. ${ }^{223}$ Younger generations are at risk of achieving the dubious distinction of being less educated, proportionally, than their parents. ${ }^{24}$ So while noteworthy progress has been made in broadening higher education access, completion rates leave much to be desired. Fortunately, given the level of public and private investments in higher education, the predominant policy focus is shifting beyond access and beginning to encompass completion.

\section{A. Completion Rates}

Completion rates vary across program and institution type. Overall, $57 \%$ of students who entered a 4-year academic program in fall 2002 graduated within 6 years. ${ }^{225}$ Put the other way, more than $40 \%$ of these individuals did not complete their programs. Associate's degree and certificate completion rates are even more dismal. Only $27 \%$ of full-time students who entered such programs in fall 2005 graduated within three years. ${ }^{226}$ By institution type, $65 \%$ of bachelor's degree seekers at private schools completed their degrees, while only $55 \%$ of those at public institutions did so-and, worse yet, only $22 \%$ of students at for-profit schools managed to finish. ${ }^{227}$

Large disparities in completion exist across racial and ethnic lines.

\footnotetext{
${ }^{221}$ PATHWAYs To Prosperity, supra note 66, at 10.

${ }^{222} \mathrm{Id}$. at 38 . But it is important to note that completion rates are measured in terms of specific timeframes, usually $150 \%$ of the intended program length, and therefore do not account for completion that occurs later. For example, failure to complete a 4-year academic program within 6 years is considered non-completion, even if the student completes the degree later. See, e.g., AUD ET AL., supra note 45, at 72.

${ }^{223}$ BRIDGELAND ET AL., supra note 131 , at 7.

${ }^{224} \mathrm{Id}$.

${ }^{225}$ AUD ET AL., supra note 45, at 72.

${ }^{226} I d$.

${ }^{227} \mathrm{Id}$.
} 
Among white, black and Hispanic students in 4-year programs, completion rates were $60 \%, 40 \%$, and $49 \%$ respectively. ${ }^{228}$ The highest completion rates were among students of Asian/Pacific Islander descent, at $67 \%$; the lowest were among Native Americans, at 38\%. ${ }^{229}$ Among white, black and Hispanic students in Associate's or certificate programs, completion rates were $29 \%, 23 \%$, and $26 \%$ respectively. ${ }^{230}$ Asian/Pacific Islanders were the only racial/ethnic group with a completion rate above $30 \% .{ }^{231}$

Socioeconomic background characteristics have been found to influence completion rates. ${ }^{232}$ A study of students at flagship public universities found that income and parents' education each influenced graduation rates. $^{233}$ On a whole, students from high-income backgrounds, with college-educated parents, were found most likely to graduate from these universities. ${ }^{234}$

The effects of socioeconomic factors on college participation and completion are topics of intense inquiry. The interest is well-placed because these factors likely provide much of the context in which disparities play out. Socioeconomic background influences pre-college academic preparation, ${ }^{235}$ college options and choices, ${ }^{236}$ and ability to pay ${ }^{237}$ in intertwining fashion. Inadequate academic preparation diminishes college participation and completion rates, disproportionately affecting students of color and the poor. ${ }^{238}$ Inadequate academic preparation, along with

${ }^{228} \mathrm{Id}$.
${ }^{229} \mathrm{Id}$.
${ }^{231} \mathrm{Id}$. at 73.
${ }^{232}$ BAUM ET AL., supra note 30 , at 34 ("High school graduates from low-income backgrounds, those whose parents did not go to college, and black and Hispanic students have lower college enrollment rates and much lower educational attainment rates than others.").

${ }^{233}$ The graduation rate for high-income students was $83 \%$, while the rate for low-income students was 70\%. After controlling for various background characteristics (e.g. entrance exam scores), parents' education and income level each contributed to the disparity. Id.

${ }^{234} I d$. at 40.

${ }^{235}$ See, e.g., Michael Kirst, Secondary and Postsecondary Linkages, in ECONOMIC INEQUALITY AND HIGHER EDUCATION 44 (Stacy Dickert-Conlin.\& Ross Rubenstein eds., 2007).

${ }^{236}$ See, e.g., MichaEl S. MCPHERSON \& MORTON OWEN SCHAPIRO, THE STUDENT AID GAME: MEETING NEED AND REWARDING TALENT IN AMERICAN HigHER EDUCATION 47 (1998).

${ }^{237} \mathrm{Id}$. at 14 (stating that the failure of student aid to keep pace with rising education costs has restricted access of low-income students to higher education).

${ }^{238}$ Kirst, supra note 236, at 44 (discussing factors that lead to subpar pre-college education of students of color and the poor). 
insufficient ability to pay, can often restrict college choices. ${ }^{239}$ Insufficient ability to pay can keep even academically qualified students from completing college - or attending at all. ${ }^{240}$ With all of these factors at play, it is easy to imagine how the disadvantages of poverty can compound, diminishing an individual's chances of completing college and resulting in the disparities discussed earlier.

\section{B. Cohort Default Rates}

Short of bankruptcy, cohort default rates are the most direct expression of educational investment failure. Cohort default rates represent the percentage of federal student loan defaulters from a particular educational institution. ${ }^{241}$ Calculating a school's cohort default rate is pretty straightforward - in theory, of course. The Department of Education (ED) identifies a cohort by determining the number of former students who went into repayment during a particular fiscal year. ED then determines the number of individuals from that cohort who have defaulted on their student loans during the "cohort default period" (usually about two years). The rate is then calculated by dividing the number of defaulters by the total number of individuals in the cohort. $^{242}$ A cohort default rate above certain thresholds could limit or eliminate a school's eligibility for federal student aid. $^{243}$ Overall, cohort default rates were $8.8 \%$ for fiscal year 2009 , up from $7 \%$ in $2008 .^{244}$ Predictably, cohort default rates vary across institution type.

${ }^{239}$ See, e.g., MCPHERSON \& SCHAPIRO, supra note 237, at 47 (observing that "[1]owincome students are increasingly rare at four-year colleges and universities" due to increased education costs).

${ }^{240}$ Edward P. St. John, The Impact of Financial Aid Guarantees on Enrollment and Persistence: Evidence From Research on Indiana's Twenty-First Century Scholars and Washington State Achievers Programs, in STATE MERIT SchOLARSHIP PROGRAMS AND RACIAL INEQUALITY 125 (Donald E. Heller \& Patricia Marin eds., 2004), available at www.civilrightsproject.ucla.edu/research/meritaid/fullreport04.php (arguing that millions of academically prepared, low income students are being denied educational opportunities due to financial difficulty).

${ }^{241}$ The Department of Education calculates cohort default rates for every college or university that receives federal financial aid funds. U.S. DEP'T OF EDUC., COHORT Default RATE GuIDE, 2.1-1 (2006) [hereinafter COHORT DEFAult RATE] http://ifap.ed.gov/DefaultManagement/guide/attachments/CDRGuideMasterSept06.pdf. ${ }^{242} I d$. at 2.1 (providing a detailed explanation of how cohort default rates are calculated, including an alternate method for schools with less than 30 student loan borrowers in a cohort).

${ }^{243} I d$. at 2.4-3 (explaining the ramifications of having cohort default rates over $25 \%$ and 40\%).

${ }^{244}$ U.S. DEP'T OF EDUC., DiRECT LOAN AND FEDERAL FAMILY EDUCATION LOAN Programs, InStitutional DEFAULT RATE COMPARISON OF FY 2007, 2008, AND 2009 
The fiscal year 2009 rates were $7.2 \%$ for public institutions, $4.6 \%$ for private institutions, and almost $15 \%$ for for-profit institutions. ${ }^{245}$ Default rates tend to increase over time, with those at for-profit schools increasing at the highest rates among all institution types. ${ }^{246}$

\section{C. "Gainful Employment" Rules}

Other measures of repayment rates are also seen as proxies for determining the extent to which an educational program is a good (or bad) investment. The ED has implemented a highly controversial set of rules which rely, in part, on repayment rates to determine whether an educational program is providing "gainful employment" opportunities for students. ${ }^{247}$ The concept of gainful employment is rooted in the consumer protection functions of the ED. All programs at for-profit institutions and those lasting less than one year at public and private institutions must "prepare students for gainful employment in a recognized occupation."248 Historically, this standard has been undefined, and therefore schools have not been required to demonstrate compliance in any specific way. ${ }^{249}$ Repayment rates play a central role in defining gainful employment and providing meaningful benchmarks for assessing compliance. For example, one path to compliance requires programs to have an aggregate loan repayment rate of at least $45 \% .{ }^{250}$ Programs with repayment rates below $35 \%$ may be deemed ineligible to receive federal financial aid funds. ${ }^{251}$

As an alternative to the loan repayment benchmarks, the rules also

COHORT DeFault RATES (2011),

http://www2.ed.gov/offices/OSFAP/defaultmanagement/instrates.html.

${ }^{245} I d$.

${ }^{246}$ See, e.g., U.S. Gen Accounting Office, Report to the Chairman, H. Subcomm. On Higher Education, Lifelong Learning and Competitiveness, Proprietary Schools: Stronger

Department Of Education Oversight Needed to Help Ensure Only Eligible Students Receive Federal Student Aid (2009), available at

http://www.gao.gov/new.items/d09600.pdf (showing default rates over a 2-, 3-, and 4-year periods for various program types).

${ }^{247}$ See, e.g., Goldie Blumenstyk, Despite Criticism, Education Department Moves Ahead with 'Gainful Employment' Rule, CHRON. OF HIGHER EDUC., May 8, 2011, available at http://chronicle.com/article/Despite-Criticism-Education/127425/. See generally, Program Integrity, supra note 200 (providing detailed presentation of proposed regulations).

${ }^{248}$ Program Integrity, supra note 200, at 112.

${ }^{249} I d$. at 14.

${ }^{250} I d$. at 20 (explaining that " $[\mathrm{t}]$ he rate would be based on the total amount of loans repaid divided by the original outstanding balance of all loans entering repayment in the prior four Federal fiscal years").

${ }^{251} I d$. at 17. 
provide standards based on debt-to-income thresholds. Programs for which the typical former student has student debt payments that are less than $8 \%$ of annual earnings and less than $20 \%$ of discretionary income are deemed compliant with gainful employment standards. ${ }^{252}$ On the other hand, programs with debt-to-income ratios exceeding $12 \%$ of annual earnings or $30 \%$ of discretionary income would become ineligible for federal student loan funding if their repayment rate is also below $35 \%$. $^{253}$

The minimum standards set out by the gainful employment rules are policy statements. The ED is saying that repayment rates below $35 \%$ and debt-to-income ratios exceeding $12 \%$ of annual earnings or $30 \%$ of discretionary income represent intolerable levels of investment failure. According to ED estimates, more than 255,000 students are enrolled in programs that would be rendered ineligible under the gainful employment rules. $^{254}$ In other words, more than a quarter million students are at the greatest risk of investment failure, typified by high student loan debt and difficulty paying it. The bulk of these students are enrolled in for-profit schools, ${ }^{255}$ and unfortunately these schools are often criticized for questionable and inappropriate enrollment practices. ${ }^{256}$

\section{INFORMATION ASSYMETRY AS INVESTMENT FRAUD}

Educational investment decisions are filled with wide-ranging uncertainty. Individuals who decide to invest in education must choose among a dizzying array of schools and programs. Compounding the inherent difficulties of this task is a lack of reliable information regarding school quality or even programmatic content. ${ }^{257}$ Worse yet, students are often unable to even ascertain the costs of their educational investments beforehand, due to "complicated pricing structures". 258 The resulting information asymmetry between schools and students contributes to what

${ }^{252} \mathrm{Id}$. at 44. See generally, id. at 35 (describing how loan debt and income are calculated).

${ }^{253} \mathrm{Id}$. at 44.

${ }^{254}$ Calculations by author. $I d$. at 54 .

${ }^{255}$ Of the 3,000 programs that would fall below ineligible thresholds, about $65 \%$ would be offered by for-profit schools, $30 \%$ by public schools, and $5 \%$ by private schools. Id. at 68 .

${ }^{256}$ See, e.g., Taylor, supra note 26, at 733 (describing the nature of misrepresentations and fraud in higher education, particularly in the for-profit sector).

${ }^{257}$ LONG, supra note 16, at 1 ("[W]ith little help families must sort through a complex menu of postsecondary institutions that differ in terms of level, sector, and focus as well as costs, admissions standards, and credentials and majors offered. Then they must put this information in perspective with their own personal situations and preferences.").

${ }^{258} \mathrm{Id}$. 
can be termed "bounded rationality"-circumstances where a rational person makes an irrational decision. ${ }^{259}$ Irrational educational decisions, principally in the form of bad school choices, often lead to education investment failure, and when this failure is the result of deception, it is akin to investment fraud.

\section{A. Difficulty Obtaining Information}

Choosing a school is a critical educational investment decision. When choosing a school, a student is not only deciding from where she will hopefully receive a diploma; she is also deciding the type of program she will undertake, which determines the credential she receives and the minimum amount of time it will take her to complete the program. Additionally, the choice of school can also determine the student's chance of completion; the educational "undermatch" phenomenon is an example of this. Researchers have found that low-income students who enroll in the most selective institutions for which they are qualified have a greater chance of completing their program than their peers who undermatch. ${ }^{260}$ If more students were aware of the importance of school characteristics, like selectivity, and if more students had access to useful information about these characteristics, there would probably be less bounded rationality among those who choose to invest in higher education.

The choice of school is often influenced by costs; however, many students lack reliable information about education costs and financial aid. For example, about 850,000 students who would likely qualify for Pell grants do not even bother to apply for them. ${ }^{261}$ Researchers tend to believe this trend results from a lack of information, given the utter irrationality of these students - the neediest - not pursuing such a favorable source of financial aid. ${ }^{262}$ Students also lack basic awareness of financial concepts that are relevant to determining education costs. In one study, only $27 \%$ of respondents could correctly answer basic questions about interest rates, inflation, and investment risk diversification. ${ }^{263}$ Socioeconomic factors

\footnotetext{
${ }^{259}$ See, e.g., Bryan D. Jones, Bounded Rationality, 2 AnNu. REV. PoliT. SCI. 298 (1999), available at $\mathrm{http}: / / \mathrm{www}$.princeton.edu/ smeunier/JonesBounded1.pdf.

${ }^{260}$ BAUM ET AL., supra note 30, at 41 ('“[U]ndermatching' is defined as having test scores and high school grades that would make acceptance at a very selective state university very probable, but enrolling instead at a less-selective institution.").

${ }^{261}$ BURDMAN, supra note 17, at 4 ("Surprising numbers of low-income students-850,000 a year, or 26 percent, according to the American Council on Education - don't apply for federal aid at all, even though they would likely qualify for Pell Grants.”).

${ }^{262} \mathrm{Id}$.

${ }^{263}$ The researchers studied financial literacy among a nationally representative sample of
} 
influenced knowledge of these concepts. ${ }^{264}$ All these trends are troubling, given research suggesting that knowledge of education costs and financial aid options influence college participation, college choice, and, in the end, college completion. ${ }^{265}$

\section{B. Unscrupulous Practices}

A particularly insidious manifestation of the information asymmetry is deception and fraud. Some colleges, particularly those in the for-profit sector, have been found to engage in deceptive and fraudulent practices in order to encourage enrollment and, in the process, secure federal financial aid funds. ${ }^{266}$ This deception is most often targeted at individuals who are most likely to be duped by it. ${ }^{267}$

In 2010, a U.S. Government Accountability Office (GAO)

23-28 year olds. The researchers posed three questions of basic financial literacy, testing knowledge of interest rates, inflation, and investment risk diversification:

Suppose you had $\$ 100$ in a savings account and the interest rate was 2\% per year. After 5 years, how much do you think you would have in the account if you left the money to grow: more than \$102, exactly \$102, or less than \$102? \{Do not know; refuse to answer\}

Imagine that the interest rate on your savings account was $1 \%$ per year and inflation was $2 \%$ per year. After 1 year, would you be able to buy more than, exactly the same as, or less than today with the money in this account? \{Do not know; refuse to answer\}

Do you think that the following statement is true or false? "Buying a single company stock usually provides a safer return than a stock mutual fund.” \{Do not know; refuse to answer?

Only $27 \%$ of respondents answered all three questions correctly, with $79 \%$ answering the interest rate question correctly, 54\% answering the inflation question correctly, and 47\% answering the investment risk diversification question correctly. ANNAMARIA LUSARDI ET AL., FINANCIALLY LITERATE AMONG THE YOUNG: EVIDENCE AND IMPLICATIONS FOR CONSUMER POLICY (2010), http://www.dartmouth.edu/ alusardi/Papers/Financial_literacy_young.pdf. ${ }^{264} I d$. at 12 .

${ }^{265}$ See, e.g., id. at 8.

${ }^{266}$ See, e.g., U.S. GOV'T ACCOUNTABILITY OFFICE, GAO-10-948T, For-Profit COLLEGES: Undercover TESTING Finds COLLEGES ENCOURAGED FrAud AND ENGAGED IN DECEPTIVE AND QUESTIONABLE MARKETING PRACTICES (2010) [hereinafter GAO UNDERCOVER TESTING], available at http://www.gao.gov/new.items/d10948t.pdf.

${ }^{267}$ Taylor, supra note 26, at 761 (asserting that "the most common targets of proprietary school advertisements are poor, undereducated, and older" and thus "highly susceptible to being persuaded by misrepresentations, due to their lack of insight about higher education"). 
undercover investigation of 15 for-profit schools found deceptive, if not fraudulent, enrollment practices at all of them. ${ }^{268}$ The deception related to graduation rates, costs, and post-employment employment prospects and salary - factors that are highly relevant to anyone attempting to determine the prudence of an educational investment. ${ }^{269}$ For example, representatives at two colleges guaranteed employment upon graduation and representatives at five colleges inflated salaries. ${ }^{270}$ Additionally, at nine colleges, undercover investigators were given deceptive information about program duration or costs. ${ }^{271}$ Representatives at six colleges deceptively told investigators that they were required to enroll prior to receiving information about financial aid eligibility. ${ }^{272}$ Representatives at four colleges encouraged investigators to falsify financial aid documents. ${ }^{273}$ One representative even told an undercover investigator that "student loans were not like car loans because "no one will come after you if you don't pay.",274 This investigation highlighted the pervasive nature of deception and fraud in higher education, as well as the informational disadvantage at which students often find themselves.

For schools, there are few disincentives to engage in deceptive or fraudulent behavior when enrolling students. The maximum fine imposed by the ED for a "substantial" misrepresentation is only $\$ 25,000,{ }^{275}$ a nominal amount in the grand scheme of things. ED can strip a school of its federal financial aid eligibility, but is reluctant to pursue such sanctions, even when appropriate. ${ }^{276}$ Making matters worse, another GAO study found the ED's methods of detecting some forms of noncompliance with financial aid rules to be inadequate. ${ }^{277}$ In addition, Federal Student Aid (FSA), the division within ED that oversees federal student aid programs,

${ }^{268}$ GAO UNDERCOVER TESTING, supra note 266, at 7.

${ }^{269} \mathrm{Id}$. at 9 .

${ }^{270} I d$. at 10

${ }^{271} I d$. at 11 .

${ }^{272} \mathrm{Id}$.

${ }^{273}$ The representatives' encouragement of this fraud was inexplicable, given that the investigators presented an ability to pay for the programs without financial aid. Id. at 7 . ${ }^{274} I d$. at 12.

${ }^{275}$ GAO UNDERCOVER TESTING, supra note 266, at 6.

${ }^{276}$ U.S. GOV'T ACCOUNTABILITY OFFICE, GAO-11-10, HighER EDUCATION: STRONGER FEDERAL OVERSIGHT NEEDED TO ENFORCE BAN ON INCENTIVE PAYMENTS TO SCHOOL RECRUITERS 33 (2010), available at http://www.gao.gov/new.items/d1110.pdf ("Education officials also noted that they have not terminated a school for incentive compensation issues. They were primarily concerned that schools would challenge terminations and Education would need to invest resources in litigating cases without necessarily prevailing in those terminations.").

${ }^{277}$ See, e.g., id. at 2. 
lists as a strategic priority the development of "compliance metrics" for identifying schools that engage in deceptive or fraudulent behavior; ${ }^{278}$ the implication being that current measures are inadequate.

\section{Few Avenues for Redress}

Schools that engage in deceptive or fraudulent practices are protected by the courts, mainly though the doctrine of academic abstention - a judicial "reluctance to intrude upon the inner workings of [higher education] institutions."279 The doctrine is a historical relic, tracing its existence to a time when colleges were operated almost exclusively by churches. ${ }^{280}$ Courts were reluctant to intrude upon the inner workings of the church, and this reluctance extended to schools, as arms of the church. ${ }^{281}$ The doctrine, however, has persisted through the advent of public colleges and universities and the secularization of most private schools. The primary modern justification is premised on a judicially-held view that courtroom fact-finders are unqualified to question the judgments of professional educators. $^{282}$

Adherence to academic abstention disadvantages victims of higher education deception and fraud who seek redress in the courts. Causes of action tend to be based on tort or contract law theories. In tort law, fraudulent misrepresentation, negligent misrepresentation, and educational malpractice are some of the most common theories of recovery. In contract law, breach of contract is probably the most common theory. In each, judicial reluctance or deference renders each theory ineffective at garnering recovery for most plaintiffs.

Fraudulent misrepresentation is difficult to prove because scienter, or intent to deceive, is difficult to prove. Typically, courts require high levels of specificity when considering whether a misrepresentation is fraudulent. ${ }^{283}$ Negligent misrepresentation is rendered mostly ineffective because "courts are reluctant to impose a duty of care upon educational

\footnotetext{
${ }^{278}$ FSA STRATEGIC PLAN, supra note 133, at 21.

279 Taylor, supra note 26, at 763.

${ }^{280}$ Kevin P. McJessy, Contract Law: The Proper Framework for Litigating Educational Liability Claims, 89 Nw. U.L. REV. 1768, 1812 (1995).

${ }^{281}$ Id.

${ }^{282}$ Taylor, supra note 26, at 763.

283 See, e.g., Schwitters v. Des Moines Commercial Coll., 203 N.W. 265, 265 (Iowa 1925)

(characterizing representations made regarding the timeline for course completion and post-graduation job acquisition as "no more than a prophecy" and thus not actionable as a basis of recovery).
} 
institutions for their student outcomes."284 Courts have cited the collaborative nature of education in reasoning that there is no objective standard of care that could be imposed upon schools. ${ }^{285}$ Courts have rendered educational malpractice, another negligence-based theory, effectively moot based on a host of considerations, including "inherent uncertainties" about the causes of the harms being alleged and the potential for a flood of litigation that could "overburden schools". ${ }^{286}$ Montana is the only state where an educational malpractice claim has been allowed to proceed. $^{287}$

Courts require that breach of contract claims allege that specific promises were broken, ${ }^{288}$ thus leaving effectively no path to recovery for plaintiffs who were duped by "legally vague, but practically convincing" promises. $^{289}$ And with a seeming nod to academic abstention, one court articulated a standard that only those contract claims that allow the court to make "an objective assessment" of whether the institution broke a promise can stand; those that require the fact-finder to consider "educational processes and theories" must be dismissed. ${ }^{290}$

The information asymmetry that characterizes the relationship between schools and students fosters bad educational choices and aids unscrupulous schools in deception and fraud. Both trends contribute to investment failure, in the form of failure to complete. Unfortunately, students who are victimized by lack of information or deceptive misinformation are offered few options for redress. And when these students leave school with crushing student loan debt, bankruptcy represents only an inconsistent source of possible relief.

\section{BANKRUPTCY AS INCONSISTENT RELIEF}

Currently, student loans are non-dischargeable in bankruptcy, unless the debtor can prove that paying the debt would be an undue hardship upon

\footnotetext{
284 Taylor, supra note 26 , at 765.

${ }^{285}$ See, e.g., Tolman v. CenCor Career Coll., 851 P.2d 203, 205 (Colo. App. 1992).

${ }^{286}$ The other cited reasons for declining to recognize educational malpractice are familiar: lack of a standard of care and a reluctance to "embroil the courts into overseeing the dayto-day operations of schools.” Ross v. Creighton, 957 F.2d 410, 414 (7th Cir. 1992).

${ }^{287} \mathrm{Id}$.

${ }^{288} \mathrm{Id}$. at 416-17.

${ }^{289}$ Taylor, supra note 26, at 767.

${ }^{290}$ See Ross, 957 F.2d at 417.
} 
him and his dependents. ${ }^{291}$ Until the mid-1970s, however, student loans were dischargeable like other forms of unsecured debt. ${ }^{292}$ The impetus behind restricting student loan discharges was the image of an "about-to-be wealthy graduate of medical school or law school" filing for bankruptcy before attempting to make any student loan payments. ${ }^{293}$ These stories fostered a perception that the federal student loan program was a boondoggle of sorts, with crafty students benefitting at the literal expense of the taxpayers. The overall increase in bankruptcies likely fueled these perceptions.

In 1970, Congress established the Commission on the Bankruptcy Laws in large part to study the causes of what the Commission termed "The Rising Tide of Consumer Bankruptcies". ${ }^{294}$ The Commission studied allegations of abuse of student loan discharges and found only limited, mainly anecdotal, evidence of such abuse. ${ }^{295}$ It nonetheless found the abuse "reprehensible" and concluded that "it poses a threat to the continuance of educational loan programs." 296 The Commission then recommended that student loans be non-dischargeable during the first five years after entering repayment, unless the debtor can prove an undue hardship. ${ }^{297}$ In 1976, Congress implemented the Commission's recommendation. ${ }^{298}$ Since then, student loan discharge has been increasingly restricted. In 1988, the fiveyear period of non-discharge was extended to seven years. ${ }^{299}$ In 1998 , the seven-year period was removed altogether, leaving an undue hardship determination as the only path to a student loan discharge. ${ }^{300}$ Inexplicably, Congress has failed to define undue hardship or provide any guidance to judges in assessing each debtor's situation. This ambiguity fosters inconsistency at practically every juncture in the process of seeking a student loan discharge.

\footnotetext{
${ }^{291} 11$ U.S.C. $\S 523(\mathrm{a})(8)(2006)$.

292 COMM'N REPORT 1997, supra note 11, at 207.

${ }^{293}$ Id. at 209.

${ }^{294}$ The Commission was made up of nine individuals appointed by the President of the U.S., the President of the Senate, the Speaker of the House, and the Chief Justice of the Supreme Court. The Commission was charged with studying and proposing reforms to the bankruptcy system. See H.R. Doc. No. 93-137, at v, 1.

${ }^{295}$ See id. at 176.

${ }^{296} \mathrm{Id}$. at $176-77$.

${ }^{297}$ Id. at 177 ("The Commission, therefore recommends that, in the absence of hardship, educational loans be nondischargeable unless the first payment falls due more than five years prior to the petition.").

${ }^{298}$ COMM'N REPORT 1997, supra note 11, at 209.

${ }^{299} I d$. at 212.

${ }^{300}$ Huey, supra note 4, at 101.
} 


\section{A. Overview of Bankruptcy}

Debt is vital to the U.S. economy, as such, so is bankruptcy. The relationship between the two is akin to that of an electrical current and a circuit breaker. Essentially, bankruptcy serves as a means of relieving pressure created by over-indebtedness. ${ }^{301}$ This relief system is critical to the proper function of an economy centered around consumption. ${ }^{302}$

The function of debt is to facilitate consumption. Debt allows for the immediate costs of consumption to be shifted to a later time, when presumably increased financial resources will allow the debtor to pay those costs. ${ }^{303}$ Student loans illustrate this function in classic fashion. Students use loans to finance their current education consumption in hopes that their education will allow them a future salary sufficient to pay off their student loans. Using debt in this manner can be, and often is, prudent. ${ }^{304}$

When determining the prudency of taking on debt, rational consumers attempt to account for future events, both expected and unexpected, that may frustrate their ability to repay the debt. ${ }^{305}$ Unfortunately, not even the most conscientious debtor can predict the future with certainty - and not every debtor is conscientious in the first place. So over-indebtedness is inevitable, ${ }^{306}$ and when the pressures of overindebtedness become unmanageable, bankruptcy is the process through which a debtor can receive relief. But in addition to relieving pressure on debtors, bankruptcy protects creditors. ${ }^{307}$ These dual purposes-relieving

${ }^{301}$ H.R. DOC. No. 93-137 , at 61 ("[T] $]$ he 'bankruptcy act . . . is designed to be a kind of safety valve for the pressures generated by the conflicts which develop where the exchange of goods and services takes place through multiple extensions of credit from a number of unconnected sources."').

302 A. Mechele Dickerson, Consumer Over-Indebtedness: A U.S. Perspective, 43 TEX. INT'L L.J. 135, 136 (2007) (“Americans are voracious consumers, but meager producers and savers.").

${ }^{303}$ BETTI ET AL., STUDY OF THE PROBLEM OF CONSUMER INDEBTEDNESS: STATISTICAL ASPECTS 1 (2001), available at http://ec.europa.eu/consumers/cons_int/fina_serv/cons_directive/fina_serv06_en.pdf.

${ }^{304}$ Id. ("When given the opportunity and in the right circumstances, we can observe that many informed consumers successfully use debt to shift expenditure from one period of their lives to another.").

${ }^{305} I d$. ("The rational consumer takes into consideration the possibility of future serious illness, unemployment or other potential negative events when he/she makes decisions such as borrowing and makes the necessary precautions, such as insurance, to the extent possible and appropriate.")

${ }^{306} \mathrm{Id}$. at 2 (" $[\mathrm{L}] \mathrm{ike}$ indebtedness, over-indebtedness is a natural phenomenon that inevitably touches a proportion of the population at any time and in any economic circumstances.").

${ }^{307}$ See, e.g., H.R. Doc. No. 93-137, at 71. 
debtors and protecting creditors - create "a system born of conflict and competing values". ${ }^{308}$ Like over-indebtedness in the economy, conflict is unavoidable in bankruptcy. ${ }^{309}$

\section{History}

The U.S. system of bankruptcy, with its dual concerns, is rather distinct in history. Early bankruptcy laws originated in Europe and only applied to merchants and commercial traders. ${ }^{310}$ Bankruptcy was an involuntary process, primarily concerned with protecting creditors by ensuring that the assets of debtors, particularly those deemed to be evading debt obligations, were liquidated and distributed fairly. ${ }^{311}$ Under these early laws, there was no discharge of unsatisfied debts, ${ }^{312}$ and debtors were considered criminal "offenders.", 313

The first bankruptcy law in the U.S. was promulgated in 1800 and was modeled after the laws in Europe. ${ }^{314}$ However, the Act of 1841 fundamentally changed bankruptcy law by allowing for a voluntary action and making it available to individual and other non-merchant debtors. ${ }^{315}$ The voluntary action introduced a largely unprecedented cooperative aspect to bankruptcy law. ${ }^{316}$ This cooperative component was rooted in English insolvency law, which was premised on providing a process by which an "unfortunate debtor" could liquidate his assets among his creditors. ${ }^{317}$ In essence, the 1841 Act provided a means for a debtor, recognizing his financial situation, to file bankruptcy on his own terms, rather than at the

${ }^{308}$ COMM'N REPORT 1997, supra note 11 , at 78.

${ }^{309} I d$. (asserting that bankruptcy "must remain unpopular and controversial" in order to serve its dual purposes).

${ }^{310}$ H.R. Doc. No. 93-137, at 63 ("[Bankruptcy laws] germinated in the law-merchant of the Italian states and elsewhere in continental Europe during the late Middle Ages as a weapon against a commercial trader who 'made bankrupt' by flight from a mercantile center . . . or ... by concealment of his property.").

${ }^{311} I d$.

${ }^{312} \mathrm{Id}$.

${ }^{313}$ Charles J. Tabb, Consumer Bankruptcy and Credit in the Wake of the 2005 Act: Abuse or Protection? The Top Twenty Issues in the History of Consumer Bankruptcy, 2007 U. ILL. L. REV. 9, 28 (2007) (remarking that bankrupt debtors were often imprisoned and fraudulent bankrupt debtors could be put to death).

${ }^{314}$ See id. at 11-12.

${ }^{315}$ H.R. DOC. No. 93-137, at 63.

${ }^{316}$ In practice, cooperative bankruptcies were not completely unprecedented prior to the 1841 Act. Creditors and debtors would sometimes enter "friendly", though still involuntary, bankruptcies. Id. at 64 .

${ }^{317}$ Id. at 63 . 
behest of a creditor. The fundamental goal of bankruptcy - the liquidation and apportionment of debtor assets to creditors - did not change; but the voluntary nature of the process represented a fundamental "sea change." "318 The Act was short-lived, as Congress repealed it after only thirteen months ${ }^{319}$ but voluntary bankruptcy became an enduring notion in future legislation.

The Act of 1898 was the first permanent federal bankruptcy law; the previous three acts - 1800,1841, and 1867-were all temporary pieces of legislation. ${ }^{320}$ Debate over the bill lasted nine years, ${ }^{321}$ with debt discharge representing a primary sticking-point. ${ }^{322}$ The law was based in large part on a fiercely pro-creditor bill drafted by Senator Jay Torrey; however, prodebtor factions were able to influence the final bill in conference, and the result has been characterized as "one of the most favorable pro-debtor relief measures ever enacted." "323 The paramount form of debtor relief- the discharge of debts - was included in the final bill. In fact, one Senator called the discharge provisions "exceedingly liberal.",324

Like voluntary bankruptcy, debt discharge has persisted as a primary component of bankruptcy law for more than 100 years. The enduring legacy of debt discharge has been its role as the basis of a central objective of bankruptcy - providing a debtor with a "fresh start". The premise of the fresh start was captured by the Supreme Court in Williams v. United States Fidelity \& Guaranty Co.: ${ }^{325}$ "to relieve the honest debtor from the weight of oppressive indebtedness and permit him to start afresh free from the obligations and responsibilities consequent upon business misfortunes." 326 In Local Loan Co. v. Hunt, ${ }^{327}$ the Court characterized the idea of a fresh start essentially as a means of integrating the bankrupt debtor back into the economy as a productive wage-earner. The Court stated that preserving the right of the debtor to exit bankruptcy with "a new opportunity in life and a clear field for future effort" "328 was "of the utmost importance . . . because it

\footnotetext{
${ }^{318}$ See Tabb, supra note 313 , at 12.

${ }^{319}$ Bradley Hansen, Bankruptcy Law in the United States, EH.NET ENCYCLOPEDIA (Aug. 14, 2001) http://eh.net/encyclopedia/article/hansen.bankruptcy.law.us.

${ }^{320}$ Charles Jordan Tabb, A Century of Regress or Progress? A Political History of Bankruptcy Legislation in 1898 and 1998, 15 BANKR. DEV. J. 343, 344, 363 (1999) (describing the bill's permanency as "a radical idea at the time").

${ }^{321} I d$. at 354 .

${ }^{322} \mathrm{Id}$. at 368 .

${ }^{323} \mathrm{Id}$. at 367 .

${ }^{324}$ Id. at 376.

${ }^{325}$ Williams v. U.S. Fid. \& Guar. Co., 236 U.S. 549 (1915).

${ }^{326}$ Id. at 554-55.

${ }^{327}$ Local Loan Co. v. Hunt, 292 U.S. 234 (1934).

${ }^{328}$ Id. at 244.
} 
is a fundamental private necessity [and] a matter of great public concern."329 The Bankruptcy Reform Act of 1978 replaced the 1898 legislation. ${ }^{330}$ One of the primary aims of the new Act was to steer bankrupt debtors away from filing under Chapter 7 and into Chapter $13 .^{331}$ The idea behind this encouragement was a belief that creditors would get paid more through Chapter 13 payments plans than they were under Chapter 7 liquidation. ${ }^{332}$ Unwilling to infringe upon debtor freewill, Congress stopped short of compelling certain debtors into Chapter 13; rather it provided incentives for such a filing. ${ }^{333}$ This policy decision demonstrated that the voluntary nature of bankruptcy remained a very important ideal. However, suspicion remained that some debtors who could afford to pay some of their debts through Chapter 13 were nonetheless filing for the broader discharge under Chapter 7. And in 2005, the Bankruptcy Abuse Prevention and Consumer Protection Act $^{334}$ passed.

The signature feature of the 2005 Act was a long-held priority of the credit industry ${ }^{335}$-a "means test" that debtors must pass in order to file under Chapter 7. ${ }^{336}$ The means test has been criticized as being sloppily written; ${ }^{337}$ but, very generally, if a debtor's income is above the applicable median income for similar households in his state, he must show that his disposable income falls below $\$ 100$ per month or $\$ 6,000$ over a five-year period. ${ }^{338}$ While very few debtors are forced into Chapter 13 by the means test, ${ }^{339}$ the fact that Congress was willing to infringe, even a little, upon the

${ }^{329} I d$. at 245 .

${ }^{330}$ Charles Jordan Tabb, The History Of The Bankruptcy Laws In The United States, 3 AM. BANKR. INST. L. REV. 5, 23 (1995).

${ }^{331}$ See id. at 35.

${ }^{332} \mathrm{Id}$.

${ }^{333}$ Id. (citing "super discharge" of certain debts that would not be dischargeable in Chapter 7 as an inducement for filing Chapter 13); see also id. at 36 (remarking that Congress granted courts the power to dismiss Chapter 7 filings that amounted to "substantial abuse" of the system, meaning it was very clear that the debtor could afford to pay some of his debts).

${ }^{334}$ Bankruptcy Abuse Prevention and Consumer Protection Act of 2005, Pub. L. No. 109-8, 119 Stat. 23 (2005).

${ }^{335}$ COMM'N REPORT 1997, supra note 11, at 90 (noting in 1997 that" [t] he credit industry has sought means testing consistently for at least 30 years").

${ }^{336}$ Dickerson, supra note Error! Bookmark not defined., at 939.

${ }^{337}$ See, e.g., Chelsey W. Tulis, Get Real: Reframing the Debate over How to Calculate Projected Disposable Income in \$ 1325(b), 83 AM. BANKR. L.J. 345, 358, 360 (2009) (describing how "confusing" language has led to conflicting interpretations of the means test).

${ }^{338}$ See Dickerson, supra note 212, at 939 (providing a detailed explanation of the means test).

${ }^{339}$ Michelle J. White, Consumer Bankruptcy and Credit in the Wake of the 2005 Act: Abuse 
debtor sanctity of choosing under which Chapter to file is significant.

Some of the most recent bankruptcy reforms were hastened by precipitous increases in the number of bankruptcy filings. The 1970 Commission noted that between 1946 and 1967, the total number of bankruptcies increased from 10,196 to 208,329 , with 191,729 being personal bankruptcies. ${ }^{340}$ The work of this Commission influenced the 1978 Act. $^{341}$ A second Commission, formally titled the National Bankruptcy Review Commission, was established in $1994,{ }^{342}$ largely in response to the 1.2 million personal bankruptcies that year. So in the less than 30 years between the two Commissions, the number of personal bankruptcies increased more than six-fold. In 2010, there were more than 1.5 million personal bankruptcies, ${ }^{343}$ the highest amount since the record 2 million in $2005 .^{344}$

As the number of bankruptcies has risen, Congress has excepted an increasing number of debt types from discharge. When a debt is excepted from discharge, it survives bankruptcy, and the debtor remains responsible for paying it. Thus, discharge exceptions are direct infringements upon the notion of a fresh start. Pre-1978, discharge was essentially an all-or-nothing proposition; the 1978 Act included nine discharge exceptions; the 2005 Act includes nineteen. ${ }^{345}$ Some debts are excepted based on public policy reasons; for instance, debt incurred through fraud cannot be discharged. ${ }_{347}^{346}$ Other debts are excepted due to "the inherent nature of the obligation". ${ }^{347}$ One such excepted debt is student loans. The oft-espoused "inherent nature" justification is that the viability of the student loan program depends

or Protection? Economics of Bankruptcy Reform under BAPCPA, 2007 U.ILL. L. REV. 275, 291 (2007) (calculating that less than 1\% of bankrupt debtors were forced into Chapter 13 because of the means test). See, also, e.g., Christian E. Weller et al., Estimating the Effect of the Bankruptcy Abuse Prevention and Consumer Protection Act of 2005 on the Bankruptcy Rate, 84 AM. BANKR. L.J. 327 (2010) (noting that while the Chapter 7 filing rate decreased after passage of the 2005 Act, this decrease was likely temporary).

${ }^{340}$ COMMISSION REPORT1973, supra note 9, at 2.

${ }^{341}$ COMMISSION REPORT 1997, supra note 11, at ii.

${ }^{342} I d$. at 47.

${ }^{343}$ U.S. BANKRUPTY COURTS-BUSINESS AND NON-BUSINESS CASES COMMENCED BY

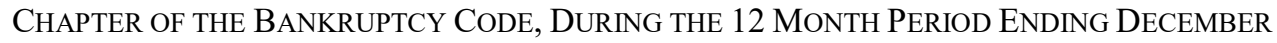
31, 2010 t. F-2 (2011)

http://www.uscourts.gov/uscourts/Statistics/BankruptcyStatistics/BankruptcyFilings/2010/ 1210_f2.pdf.

${ }^{344}$ The number of bankruptcies in 2005 was likely inflated by debtors clamoring to file just before the new, more restrictive, bankruptcy laws took effect in October of that year.

Dickerson, supra note 302, at 148.

${ }^{345}$ Tabb, supra note 330 , at 7.

${ }^{346}$ COMMISSION REPORT 1997, supra note 11, at 179.

${ }^{347} \mathrm{Id}$ 
on debtors making good on their obligations. ${ }^{348}$

\section{B. Undue Hardship Standard}

Bankruptcy courts have struggled with the mere definition of undue hardship. Should the words be construed literally or conceptually? Should the words be defined separately or together? The In re Heckathorn court stated that undue hardship was a "phrase with a particular legal meaning and function". ${ }^{349}$ Conversely, the In re Skaggs court reasoned that "the plain, ordinary meaning" of the words was sufficient in taking a "common sense" approach to defining the concept. ${ }^{350}$

Some courts seem to struggle with determining the extent or degree of hardship that should be embedded in their definitions, suggesting that "undue" is the more problematic component of the concept. The In re Brunner court stated that "garden-variety" hardships are not "undue.",351 The court suggested that undue hardship required a "certainty of hopelessness" about a debtor's ability to fulfill her payment obligations. ${ }^{352}$ In contrast, the court in Kopf v. Dep't of Educ. ${ }^{353}$ stated that a "certainty of hopelessness" standard is antithetical to the fresh start ideal; thus, it applied a standard that only required debtors to show a "reasonable" chance that paying their loan would force them to live below a "minimal standard of living." 354 Frustrated by the ambiguous standards and thresholds applied in undue hardship cases, the In re Bryant court tied undue hardship to federal poverty guidelines - an objective benchmark. ${ }^{355}$ According to the court, if a debtor's net income is "at, near or below" the poverty rate or if a debtor's income is above the rate, but she has sufficiently "unique" or "extraordinary" expenses, the payments represent an undue hardship. ${ }^{356}$ So the degree of hardship required by courts has ranged from "reasonable" to "certain" and has been tied to poverty rates.

Most courts agree that in order for a hardship to be "undue," it must

${ }^{348}$ See, e.g., In re Claxton, supra note 3, at 568.

${ }^{349}$ In re Heckathorn, 199 B.R. at 194.

${ }^{350}$ In re Skaggs, 196 B.R. at 867.

${ }^{351}$ In re Brunner, 46 B.R., at 753.

${ }^{352} \mathrm{Id}$. at 755 .

353245 B.R. 731 (Bankr. D. Me. 2000)

${ }^{354}$ Id. at 745 .

355 Bryant v. Pennsylvania Higher Educ. Assistance Agency (In re Bryant), 72 B.R. 913, 915 (Bankr. E.D. Pa. 1987) ("We feel that such a test will decrease, if not eliminate, the resort to the unbridled subjectivity which seems to pervade many of the decisions in [undue hardship cases].").

${ }^{356} I d$ 
persist into the future. The Heckathorn court stated that in addition to demonstrating current inability to pay, debtors are expected "to show also that they cannot reasonably be expected to make payments...in the foreseeable future." 357 The In re Coleman court characterized the debtor's threshold burden as proving "that he does not now, and will not in the future, have the funds available from which to repay the student loan., 358 However, the Skaggs court, with its plain meaning approach, reasoned that current inability to pay, by itself, could represent an undue hardship. ${ }^{359}$

\section{Tests}

Some courts have devised multi-faceted tests essentially to detect an undue hardship when considering a debtor's case.

\section{a. Brunner}

The most popular test was devised by the Brunner court. ${ }^{360}$ The Brunner test requires debtors seeking a student loan discharge to show the following three things:

1) that the debtor cannot, based on current income and expenses, maintain a "minimal" standard of living for himself or herself and his or her dependents if forced to repay the loans, 2) that this state of affairs is likely to persist for a significant portion of the repayment period of the student loan, and 3) that the debtor has made good faith efforts to repay the loans. ${ }^{361}$

In essence, the test requires debtors to show that their loan payments would require them to sacrifice basic necessities, both presently and for a number of years in the future, and that they have made reasonable attempts to repay the debt. The subjectivity and ambiguity are apparent, even in this truncated explanation. What is a "minimal standard of living"? ${ }^{362}$ How is

\footnotetext{
${ }^{357}$ In re Heckathorn, 199 B.R. at 193.

${ }^{358}$ Coleman v. Higher Educ. Assistance Foundation (In re Coleman), 98 B.R. 443, 451 (Bankr. S.D. Ind. 1989).

${ }^{359}$ In re Skaggs, 196 B.R. at 868.

${ }^{360}$ Nine judicial circuits have adopted the Brunner test. State Univ. New York-Student Loan Service Center et al. v. Menezes, 2006 U.S. Dist. LEXIS 65464 (D. Mass. 2006).

${ }^{361}$ In re Brunner, 46 B.R. at 756.

${ }^{362}$ Rafael I. Pardo \& Michelle R. Lacey, The Real Student-Loan Scandal: Undue Hardship Discharge Litigation, 83 AM. BANKR. L.J. 179, 197 (2009) ("The doctrine fails to set forth even the rough contours of how to engage in a substantive evaluation of income and expenses...Instead, the doctrine merely confirms that courts have free rein to infuse
} 
inability to pay for "a significant portion of the repayment period" predicted? What constitutes "good faith efforts"? $^{364}$ These are all questions that remain unclear because undue hardship remains undefined.

b. Johnson

Some courts have chosen to adopt the test devised by the In re Johnson court. ${ }^{365}$ Under this test, debtors are required to pass an "undue hardship" test that accounts for their current and future sources of income and their expenses. ${ }^{366}$ Debtors must show, given their expenses, their income is insufficient to meet their loan obligations. Their expenses must be "reasonable" in order to pass scrutiny. ${ }^{367}$ Debtors who pass the undue hardship test must then pass either a "good faith" test or a "policy" test. The Johnson good faith test requires debtors to have made attempts to repay the loan; in making this assessment, the test looks at debtor attempts at finding employment, minimizing expenses, and maximizing income. ${ }^{368}$ If a debtor fails the good faith test, the court will apply a policy test. The purpose of the policy test is to assess whether granting the discharge would represent an abuse of the bankruptcy laws. ${ }^{369}$ This assessment hinges largely on the percentage of the debtor's total debt that is made up of student loans. $^{370}$ The higher the percentage, the more likely courts will view a discharge as abusive. The test also considers the financial benefit the debtor has received from her education. ${ }^{371}$ Debtors who have received little or no benefit are more likely to have their loans discharged.

In summary, the Johnson test requires debtors to first demonstrate that their current income is insufficient to make loan payments and this insufficiency will persist. They must also show that their expenses are reasonable. They must then show either that they have made diligent attempts to pay the loans by maximizing income and minimizing expenses

subjectivity into what should be a straightforward financial calculation.").

${ }^{363} I d$. at 198 (describing attempts by the Ninth Circuit to apply objective factors to determine future inability to pay, but lamenting that a "multifactor test within a multifactor test" is not "a realistic way to accomplish consistent results.").

${ }^{364} \mathrm{Id}$. at 200 ("Given the inherent subjectivity in an amorphous standard such as good faith, any efforts to clarify its meaning will probably create mischief rather than produce clarity.").

3651979 U.S. Dist. LEXIS 11428 (D. Pa. 1979)

366 This test is also referred to as the "mechanical" test. Id. at 35.

${ }^{367}$ Id. at 31 .

${ }^{368} I d$. at 44.

${ }^{369} \mathrm{Id}$. at 52.

${ }^{370} \mathrm{Id}$. at 54 .

${ }^{371}$ Id. at 55. 
or that they have received little financial benefit from their education and discharging student loans is not their overwhelming reason for filing bankruptcy. Like Brunner, critical elements of the Johnson test are based on ambiguous concepts.

\section{c. Bryant}

The least popular test is the most objective. As stated earlier, the In re Bryant court attempted to devise an objective test by tying undue hardship to net income and poverty benchmarks. In an effort to minimize subjective "moral judgments", the court assumes pre-bankruptcy good faith on the part of debtors. ${ }^{372}$ But the process of determining net income can be knotty when a debtor is claiming unique or extraordinary expenses; creditors can challenge the uniqueness or extraordinariness of these expenses. ${ }^{373}$ But of all the tests, the Bryant test makes the most explicit effort to base undue hardship determinations on an objective measure.

\section{d. Totality of the Circumstances}

Some courts eschew reliance on tests altogether. These courts tend to take a "totality of the circumstances" approach to making undue hardship determinations. Recognizing that there was no "universally accepted" test of undue hardship, ${ }^{374}$ the Coleman court stated "rigid adherence...to a particular test robs the court of the discretion envisioned by Congress" in devising the undue hardship standard. ${ }^{375}$ The court further stated that "[a]n undefined and illusive concept such as 'undue hardship' should result from a fact-sensitive analysis based on the totality of the circumstances." ${ }^{376}$ As a result, the court adopted a nine-prong test that assessed the debtor's revenue and expenses; past job history; rate of pay; skills and education; maximization of income; prudence of expenses; cause of insolvency; any medical problems; and any dependents. ${ }^{377}$

The Kopf court adopted a three-prong test that assessed a debtor's past, present, and future income; his living expenses; and other relevant factors, such as medical problems. In eschewing the prevailing tests, that court reasoned that Johnson and Brunner "[tested] too much", specifically

${ }^{372}$ In re Bryant, 72 B.R at 918.

${ }^{373} I d$. at 919.

${ }^{374}$ In re Coleman, 98 B.R. at 448.

${ }^{375} \mathrm{Id}$. at 451 .

${ }^{376} \mathrm{Id}$.

${ }^{377} \mathrm{Id}$. 
good-faith (in the case of both tests) and policy (in the case of Johnson). ${ }^{378}$ Oddly, Bryant was disregarded not on its merits, but because few other courts had adopted it. ${ }^{379}$ Substantively, the Kopf and Coleman totality approaches are very similar; the primary difference is how factors are categorized. In Kopf, "other circumstances" acts as a catchall capturing many of the factors that Coleman specifically enumerates. ${ }^{380}$ The problem with both approaches is that they embrace the subjectivity and moral judgments that lead to inconsistent undue hardship determinations.

\section{Relief}

The ambiguity of the undue hardship standard has fostered another area of inconsistency: undue hardship relief. Three approaches have emerged when determining appropriate relief when undue hardship is found: full discharge, partial discharge, and "hybrid" discharge. Unfortunately, Congress has failed to provide clarity, and therefore courts continue to grapple with this issue.

\section{a. Full Discharge}

Courts that view undue hardship relief as a full, all-or-nothing, proposition typically base their approach on what they view as the plain language of the statute. For example, the Skaggs court reasoned that the plain-meaning definition of "debt" in the Bankruptcy Code encompasses the entire debt, not some part. ${ }^{381}$ According to the court, Congress could have used language authorizing partial discharge, but chose not to do so, ${ }^{382}$ and "courts are not granted power to remedy perceived defects in legislation.",383

\section{b. Partial Discharge}

Courts that grant partial discharges base their approach on the equity function of bankruptcy and their interpretation of Congressional intent. The Heckathorn court emphasized that the bankruptcy process is "embedded in equity;" $" 384$ as such, courts are allowed, if not required, to grant partial

\footnotetext{
${ }^{378}$ Kopf, supra note 7, at 741.

${ }^{379}$ Id. at 737.

${ }^{380}$ Examples include medical problems and dependents. Id. at 746.

${ }^{381}$ In re Skaggs, 196 B.R. at 866.

${ }^{382}$ Id.

${ }^{383} \mathrm{Id}$. at 867.

${ }^{384}$ In re Heckathorn, 199 B.R. at 194.
} 
discharges where appropriate. The court also reasoned that because "[t]he words 'undue hardship' suggest a matter of degree", viewing discharge from an all-or-nothing perspective would lead to "absurd" results, in light of Congress's goals of providing fresh starts and maximizing student loan payments. ${ }^{385}$ In essence, discharging loans to the extent that they represent an undue hardship - and no more-will result in debtors getting the relief Congress intended while ensuring that they still pay what they can.

The Skaggs court characterized the arguments in favor of partial discharges thus: Courts that only grant full discharges reward "irresponsible debtors who create their own hardship by borrowing excessively and unrealistically for their education, while punishing the debtor who has borrowed more frugally and for whom, therefore, repayment is not an "undue hardship.",386 As the arguments goes, all-or-nothing approaches incentivize excessive student loan indebtedness. The Skaggs court concluded, however, that such arguments were "better made to Congress than to the courts." 387

\section{c. Hybrid Discharge}

The hybrid discharge approach is essentially an amalgamation of the full and partial discharge approaches. Courts that grant hybrid discharge agree that the plain-language of the undue hardship standard does not allow for partial discharge of aggregate student loan debt. ${ }^{388}$ But these courts also agree that bankruptcy is an equity process and all-or-nothing discharges may not adequately serve this function. ${ }^{389}$ Hybrid courts resolve these seemingly contradictory views by reasoning that while aggregate debt cannot be partially discharged, individual loans making up that aggregation can be discharged as necessary to prevent undue hardship. ${ }^{390}$ In other words, if a debtor has multiple student loans (as is often the case), some of those loans can be discharged while others can be deemed nondischargeable. In fact, hybrid courts reason that treating separate debts collectively runs afoul of the plain language of the undue hardship statute. $^{391}$

The In re Grigas court determined which of the debtor's fifteen

${ }^{385}$ Id. at 196.

${ }^{386}$ In re Skaggs, 196 B.R. at 866.

${ }^{387} \mathrm{Id}$. at 867.

${ }^{388}$ In re Grigas, 252 B.R. at 872.

${ }^{389} I d$. at 873 .

${ }^{390} I d$.

${ }^{391} I d$. 
loans were dischargeable by first determining that $\$ 224$ was the maximum monthly student loan payment the debtor could make without experiencing undue hardship. ${ }^{392}$ The court then considered each loan in chronological order, oldest to newest, to ascertain whether it could be paid in full within 15 years, using \$224 per month as the original benchmark. ${ }^{393}$ Through this process, as loans are deemed fully payable, and therefore nondischargeable, the monthly amount is adjusted accordingly, leaving less money to pay later loans. ${ }^{394}$ For example, if Loan \#1 was fully payable in 15 years at $\$ 100$ per month, Loan \#2 would have to be payable in 15 years at no more than $\$ 124$ per month in order to be non-dischargeable. If a loan is too large to be fully repaid, that loan would be discharged and later loans would be considered until the maximum monthly allotment is depleted. ${ }^{395}$ This method advantages older loans and smaller loans.

\section{Empirical Studies}

An empirical study of student loan discharge cases confirmed that the ambiguity of the undue hardship standard resulted in inconsistent decisions. Researchers reviewed undue hardship determinations rendered between October 7, 1993 and October 6, 2003. ${ }^{396}$ In total, the researchers reviewed 286 determinations, representing every federal circuit and $70 \%$ of the federal districts. ${ }^{397}$ The researchers found that $57 \%$ of the debtors were granted some form of undue hardship relief. ${ }^{398}$ When the researchers compared the group that received relief to the group that did not, they found an "overall lack of dissimilarity" 399 - meaning the two groups were virtually identical in relevant ways. For example, the researchers found no statistically significant difference in the median monthly disposable household income, ${ }^{400}$ median levels of student loan debt, or median debt-to household ratios of the two groups. ${ }^{401}$ The researchers did find an

${ }^{392}$ Id. at 876 .

${ }^{393} I d$.

${ }^{394} I d$.

${ }^{395} I d$.

${ }^{396}$ Rafael I. Pardo \& Michelle R. Lacey, Undue Hardship in the Bankruptcy Courts: An Empirical Assessment of the Discharge of Educational Debt, 74 U. CIN. L. REV. 405, 434 (2005).

${ }^{397}$ Id. at 437 .

${ }^{398} I d$. at 479 (describing relief as being "in the form of full discharge, partial discharge, or equitable adjustment [e.g. abatement of accrual of interest, deferment of payment]").

${ }^{399} I d$. at 481 .

${ }^{400} \mathrm{Id}$. at 483 .

${ }^{401} I d$. at 484 . 
association between health problems and the granting of undue hardship relief, but concluded that the existence of health problems alone could not explain why some debtors received relief and others did not. ${ }^{402}$ As such, the researchers concluded that "problems of uncertainty and unequal treatment of debtors" were rife in undue hardship cases, "[undermining] the integrity of the system by producing haphazard results." 40

Another study by the same researchers found that the extent of undue hardship relief was based on factors other than those relevant to debtors' ability to repay their loans. The researchers studied 115 undue hardship proceedings that had been commenced between January 1, 2002 and December 31, 2006 and resolved by August 2007. ${ }^{404}$ They chose to base their study in the Western District of Washington because it "appears to be a microcosm of the rest of the nation.." ${ }^{405}$ In $57 \%$ of the 115 cases, debtors received some form of undue hardship relief. ${ }^{406}$ A quarter of debtors who received relief were granted full discharges; half were granted discharges of about $71 \%{ }^{407}$ The average discharge was $62 \%{ }^{408}$ The researchers identified five determinants of the extent of discharge. ${ }^{409}$ Three of the five determinants were counsel's years of experience; the identity of the judge assigned to the case; and whether the case was settled or went to trial. ${ }^{410}$ These are all factors that should be irrelevant to determining the merits of an undue hardship case; however, they make up a majority of the factors that determine undue hardship relief.

These findings provide compelling support for a new framework for determining the propriety of student loan bankruptcy discharges. This framework should be unambiguous and objective, thereby lending consistency to student loan discharge cases.

${ }^{402} I d$. at 485 ("While an association certainly exists between (1) the poor health of the debtor and/or the poor health of the debtor's dependents and (2) the grant of discharge...that association alone does not explain the outcome in the undue hardship cases we have analyzed.").

${ }^{403} I d$. at 520.

${ }^{404}$ Pardo \& Lacey, supra note 362, at 203.

${ }^{405}$ The researchers cited the Western District's higher education attainment, percentage of college graduates with student loan debt, and bankruptcy filing rate to illustrate how the District's demographics are similar to those of the nation. Id. at 201.

${ }^{406} I d$. at 213.

${ }^{407} I d$.

${ }^{408} \mathrm{Id}$.

${ }^{409} \mathrm{Id}$. at 229.

${ }^{410}$ The other two determinants were the "aggregate factor count" (a cumulative measure of indicator variables designed by the researchers) and the amount of student loan debt for which discharge was being sought. $I d$. 


\section{DEBT SERVICE THRESHOLDS AS OBJECTIVE BENCHMARKS}

This section will present a framework for using debt service thresholds to determine the propriety of federal student loan bankruptcy discharges. The framework is centered around debt service thresholds because they provide critical, albeit less than absolute, objectivity to a process that is woefully subjective. The goals of the framework are twofold: 1) to provide an impartial, economical, and uniform means of assessing the propriety of student loan discharges, and 2) to provide debtors facing crushing student loan debt and few prospects for repaying it with a simplified avenue of relief in bankruptcy.

The 1994 Bankruptcy Commission lamented the "luck-of-the-draw justice" endemic of bankruptcy litigation. ${ }^{411}$ The Commission noted that throughout its review it heard complaints from debtors and creditors alike regarding inconsistency and subjectivity across the system. ${ }^{412}$ Before that, the 1970 Bankruptcy Commission observed that the "lack of uniform standards creates many variations in district court practices, and they, in turn, cause unequal treatment of creditors and debtors." also identified four objectives of the administration of bankruptcy laws. ${ }^{414}$ Three of the four-impartiality, economy, and uniformity - are frustrated by inconsistency and subjectivity. As such, bankruptcy laws should be clear, allowing for fair, efficient, and consistent resolution of cases.

Simplicity is an essential component of any rule intent on fostering consistent results. As argued by the 1994 Commission, "[a] relatively simple standard reduces litigation costs while it increases the predictability of outcomes...A simple standard also promotes consistency in application among different judges and different districts, increasing the likelihood that similar cases will be analyzed using similar legal principles." ${ }^{\text {,15 }}$ The 1970 Commission tied simplicity to access to bankruptcy. It warned that the cost

411 COMMISSION REPORT 1997, supra note 11, at 81.

${ }^{412} I d$. ("From the first hearing, the Commission heard from both debtors and creditors that some determinations that should apply consistently throughout the system have been left to individual judges and trustees.").

${ }^{413}$ COMMISSION REPORT 1973, supra note 9, at 3.

414 "There should be four objectives in the administration of the bankruptcy process: impartial, expert, and speedy performances of decision-making and other functions necessary to bring a case to a fruitful conclusion; economy that avoids waste, duplication, dilatoriness, an inefficiency; uniformity in case procedure and in the application of substantive laws throughout the United States; and managerial flexibility that can adjust quickly and efficiently to changes in quantity, kind, size, and location of cases." Id. at 81 .

${ }^{415}$ COMISSION REPORT 1997, supra note 11 , at 248. 
of bankruptcy litigation "is often disproportionate to the amounts of money involved," resulting in "genuine controversies" being left unresolved. ${ }^{416}$ This point is important because many commentators have argued that "[ $t]$ he borrowers most likely to prevail [in bankruptcy] are those with the least possibility of being able to litigate the question." ${ }^{, 417}$ As a result, the 1970 Commission concluded that "substantive laws, procedural rules, and administrative practices should be simplified and clarified to permit broader debtor, creditor, and counselor participation [in the bankruptcy process]." 418 Accordingly, "elaborate adjudication should be the exception, not the rule. $"$ "19

As discussed earlier, the fresh start notion and the post-bankruptcy discharge of debts are integral components of bankruptcy law. However, the subjective and restrictive nature of the undue hardship standard renders these integral notions needlessly speculative for debtors facing crushing student loan debt and few prospects for repaying it. The following proposed framework represents an impartial, economical, uniform and simplified alternative to the undue hardship standard.

\section{A. Proposed Framework}

In order to be eligible for discharge of federal student loans obtained in a bachelor's degree (or lower) program:

- The debtor must have been in repayment for at least five years.

In order to be eligible for discharge of federal student loans obtained in a graduate or professional school program:

- The debtor must have been in repayment for at least ten years.

In addition, the following criteria would apply to all debtors seeking federal student loan discharge:

- The debtor must have participated in the federal Income-Based Repayment (IBR) Plan or a similar plan for at least three years for all student loans for which discharge is being sought.

- The debtor's Standard monthly payment amount (aggregated over the year) must have been above applicable maximum debt service thresholds for five consecutive years leading up to discharge.

\footnotetext{
${ }^{416}$ COMISSION REPORT 1973, supra note 9, at 82.

${ }^{417}$ COMISSION REPORT 1997, supra note 11, at 212.

${ }^{418}$ COMISSION REPORT 1973, supra note 9, at 76.

${ }^{419} \mathrm{Id}$. at 82 .
} 
Upon discharge of student loans:

- The debtor is ineligible to receive future federal student loans, unless discharged loans are reaffirmed.

\section{Mandatory Repayment Periods}

As the Heckathorn court stated, some level of debt-induced hardship is to be expected early in one's post-college career. ${ }^{420}$ As such, the purpose of the mandatory repayment periods is to allow debtors an opportunity to realize some benefit from their education and to make loan payments before resorting to bankruptcy. The mandatory repayment periods would be exclusive of grace periods, deferments, forbearances, and any other periods during which the debtor is not required to make payments. The time periods can be non-consecutive.

The five-year mandatory repayment period for bachelor's degree (or lower) program debtors is borrowed from the original recommendation by the 1970 Commission that was later adopted by Congress in 1976. The tenyear mandatory repayment period for graduate and professional school program debtors mirrors the length of the Standard repayment period for federal loans. $^{421}$

The purpose of the longer mandatory repayment period for graduate and professional school debtors is to allow them ample time to realize a payoff from their education before seeking discharge. As discussed earlier, wages for workers with graduate or professional degrees exceed those associated with lower levels of education, and those wages have increased very robustly over the last 30 years. Moreover, economic trends suggest that these workers will have an increasing advantage in the scrum for stable, well-paying employment going forward.

BLS projects that through 2020, job growth will be greatest in occupations that require a master's degree, followed by those requiring a doctoral or professional degree. $^{422}$ Thus, a longer mandatory repayment period for these debtors is reasonable, given the favorable employment prospects afforded highly educated individuals in this country. And to the

${ }^{420}$ In re Heckathorn, 199 B.R. at 193.

${ }^{421}$ MANAGE Your DeBT, supra note 140, at 25.

${ }^{422}$ BLS makes the following 2010-2020 projections (in order of intensity): Master's degree: $21.7 \%$, Doctoral or professional degree: 19.9; Associate's degree: 18\%; Some college: $17.5 \%$; Postsecondary certificate: $16.9 \%$; Bachelor's degree: $16.5 \%$; Less than high school: $14.1 \%$; and High school diploma/GED: $12.2 \%$. Overall job growth is projected to be $14.3 \%$. U.S. DEP'T OF LABOR, BUREAU OF LABOR STATISTICS, EMPLOYMENT PROJECTIONS: 2010-20 (2012), available at http://www.bls.gov/news.release/pdf/ecopro.pdf. 
extent that the solvency of the federal student loan program would be threatened by this framework, debtors in the best position to leverage their education in the job market should be encouraged to make payments on their loans, even if through an income-based plan.

\section{Participation in Income-Based Repayment Plan}

The requirement that debtors participate in a federally-sponsored income-based repayment plan for at least three years is intended to ensure that debtors take advantage of options other than bankruptcy before seeking discharge. By reducing the debtor's monthly payment, such plans may be effective at directing debtors away from bankruptcy.

Currently, the federal government offers three income-based student loan repayment plans: Income-Based Repayment (IBR) Plan; Income Contingent Repayment (ICR) Plan; and Income-Sensitive Repayment Plan. ${ }^{423}$ IBR is the broadest of the plans, with applicability to all types of federal student loans, ${ }^{424}$ rendering the other plans virtually obsolete. Through IBR, debtors are required to pay no more than $10 \%$ of their "disposable income"-defined as the difference between their Adjusted Gross Income and $150 \%$ of the poverty level. ${ }^{425}$ The difference between payments made under the Standard plan and the IBR Plan can be significant for some debtors, with the latter being lower. ${ }^{426}$ Monthly payments are adjusted each year based on the debtor's family and financial situation, and after 20 years, any remaining loan balance is canceled. ${ }^{427}$

\section{Maximum Debt Service Thresholds}

Debt service thresholds will be used to determine whether a debtor's student loan payments are high enough to warrant discharge. Debt service, often expressed as a percentage, is essentially a measure of indebtedness. ${ }^{428}$ Unfortunately, there is no universally agreed upon definition or numerical

\footnotetext{
${ }^{423} \mathrm{Id}$. at 26 (providing an overview of all the income-based repayment plans and the types of loans to which they apply).

${ }^{424} \mathrm{Id}$.

${ }^{425} \mathrm{Id}$.

${ }^{426}$ U.S. DEP'T OF EDUC., FED. STUDENT AID, INCOME-BASEd REPAYMENT Plan, available at http://studentaid.ed.gov/PORTALSWebApp/students/english/IBRPlan.jsp (providing an example of a debtor whose payments under IBR would be less than half of Standard payments).

${ }^{427}$ MANAGE Your DeBT, supra note 140, at 26.

${ }^{428}$ See, e.g., BAUM \& SCHWARTZ, supra note 111.
} 
threshold of over-indebtedness. ${ }^{429}$ Thus, defining what constitutes excessive debt is an inherently arbitrary exercise. With that said, however, there are generally accepted benchmarks that are relied upon by loan underwriters and others who seek to assess loan risks. ${ }^{430}$ And while these benchmarks are not applicable to every debtor's situation, they are nonetheless helpful at providing common bases upon which to assess a range of debtors.

The maximum debt service thresholds for this framework were set using as guidance a model developed by researchers at the College Board. The College Board model uses income levels and the poverty rate to determine the maximum annual amount a debtor can dedicate to student loan payments. ${ }^{431}$ The model determines maximum annual student loan payments by applying a uniform debt service of $20 \%$ to an individual's "disposable income"-defined as income above $150 \%$ of the poverty threshold. ${ }^{432}$

The framework proposed in this article is less generous than the College Board model. Maximum debt service thresholds begin at $20 \%$ and reach as high as $30 \%$ of a debtor's disposable income. This graduated approach acknowledges, albeit somewhat arbitrarily, that individuals "with higher incomes can afford to devote a higher proportion of their incomes to debt payments without sacrificing basic expenditures." ${ }^{233}$ In addition, the College Board's threshold is intended to be a prudency standard, not necessarily a measure of when bankruptcy discharge is appropriate.

The maximum annual amount a debtor can dedicate to student loan payments is calculated in the following manner:

- Determine "disposable income" by calculating the difference between the debtor's gross income and $150 \%$ of the federal poverty threshold for similarly-situated debtors. ${ }^{434}$ Gross income is defined as income from all sources, including employment and domestic

\footnotetext{
${ }^{429}$ BETTI ET AL., supra note 303, at 59 ("“T] appropriate concepts of consumer indebtedness, on how to measure it or on where to draw the line between normal and excessive / over-indebtedness.").

${ }^{430}$ See, e.g., BAUM \& SCHWARTZ, supra note 111, at 2 (describing the commonly-cited view that student loan payments should not encumber more than $8 \%$ of gross income). ${ }^{431} I d$. at 11 .

${ }^{432} I d$. at 12.

${ }^{433} I d$. at 11 .

${ }^{434}$ The U.S. Dep't of Health and Human Services publishes poverty guidelines each year. Poverty thresholds are based principally on the number of persons in a family. For example, the poverty threshold for a 4-person family in the 48 contiguous states and DC is $\$ 22,350$; the threshold is $\$ 14,710$ for a 2-person family. Annual Update of the HHS Poverty Guidelines, 76 Fed. Reg. 13 (Jan. 20, 2011), available at http://aspe.hhs.gov/poverty/11 fedreg.pdf.
} 
support. If the debtor is married and not separated, spouse's income is also included in the gross income calculation.

- The following student loan debt service thresholds are then applied to the disposable income calculation:

\$1-49,999 (disposable income): 20\% (debt service threshold) $\$ 50,000-74,999: 22.5 \%$

$\$ 75,000-99,999: 25 \%$

$\$ 100,000-124,999: 27.5 \%$

$\$ 125,000+: 30 \%$

So a debtor with gross income of $\$ 40,000$ and a family size of three (including the debtor herself) will have disposable income of $\$ 12,205-$ which is the difference between the debtor's gross income and $150 \%$ of the poverty threshold $(\$ 27,795)$ for her family. The applicable student loan debt service threshold is $20 \%$--which means that for purposes of her bankruptcy petition, the maximum amount this debtor could dedicate to student loan payments for the year in question is $\$ 2,441$, or $6 \%$ of her gross income. Student loan obligations above that amount would render the payments, in effect, an undue hardship for that year.

Higher gross income or smaller family size can lead to higher maximum annual student loan payments. For example, a debtor with gross income of $\$ 60,000$ and a family size of three would have disposable income of $\$ 32,205$ (\$60,000 - \$27,795). The applicable student loan debt service threshold is $20 \%$--which means that for purposes of his bankruptcy petition, the maximum amount this debtor could dedicate to student loan payments for the year in question is $\$ 6,441$, or about $11 \%$ of his gross income.

A debtor with gross income of $\$ 40,000$ and a family size of one would have disposable income of $\$ 23,665(\$ 40,000-\$ 16,335)$. The applicable student loan debt service threshold is $20 \%$--which means that for purposes of her bankruptcy petition, the maximum amount this debtor could dedicate to student loan payments for the year in question is $\$ 4,733$, or about $12 \%$ of her gross income.

\section{Five Years of Above-Maximum Payments}

In order to be eligible for discharge, the debtor's monthly payments (aggregated over the year) must exceed the stipulated maximum amounts for five consecutive years. Calculations will be made for each relevant year to account for changes in salary, poverty thresholds, and payment obligations.

The Standard repayment plan will be used to determine payment obligations, even if the debtor made payments under an income-based plan. 
The proposed framework requires debtors to enroll in such a plan, in order to lower their monthly payments. But relying on these lower payments in determining eligibility for discharge would essentially punish the debtor. Thus, reliance on the Standard plan (which represents the maximum most debtors can be obligated to pay) is premised on the idea that debtors should not be punished for attempting to lower their payments and exhaust options short of discharge.

Further, an income-based repayment plan should not be considered a substitute for bankruptcy discharge. One court argued that such a consideration allows judges to abdicate their responsibility of determining appropriate bankruptcy relief. ${ }^{435}$ Additionally, adherence to an incomebased repayment plan can yield a non-dischargeable tax obligation for the debtor. For example, after 20 years of making payments through the IBR Plan, any remaining loan balance is canceled; but the debtor may be required to report this canceled balance as taxable income. ${ }^{436}$ As the Bronsdon court put it, debtors should not be forced to trade "a nondischargeable student loan debt for a non-dischargeable tax debt." ${ }^{437}$

Debtors with multiple loans can choose on which loans to seek discharge; however, loans must be discharged in chronological order, from newest to oldest. The latter restriction is an intuitive response to the ordinal manner in which degrees are earned, and means that in all but the rarest cases, debtors with graduate or professional school loans will have to successfully discharge those loans prior to being able to discharge bachelor's degree (or lower) loans.

For purposes of determining discharge eligibility, a debtor's payments on all student loans will be considered, even if the debtor is not seeking discharge on all loans. The purpose of this approach is to give the court complete insight into the debtor's financial picture.

\section{Reestablishing Loan Eligibility}

Debtors could reestablish eligibility for federal student loans by satisfying the Federal Student Aid (FSA) process for restoring loan eligibility—essentially reaffirming their discharged student loan debt. FSA

\footnotetext{
${ }^{435}$ Denittis v. Educ. Credit Mgmt. Corp. (In re Denittis), 362 B.R. 57, 64 (Bankr. D. Mass. 2007) ("To hold that debtors must participate in [an income-based repayment plan], if eligible, would be no more than the Court abdicating its responsibility to determine the dischargeability of a student loan. If this is the outcome Congress intended, it would have said so".).

${ }^{436}$ MANAGe Your DeBT, supra note 140, at 26.

${ }^{437}$ Bronsdon v. Educ. Credit Mgmt. Corp. (In re Bronsdon), 435 B.R. 791, 803 (Bankr. 1st Cir. 2010).
} 
provides four options for restoring loan eligibility to debtors who have defaulted: 1) pay the loans in full; 2) make six payments of an agreed amount over a six month period; 3) consolidate loans through a federallyapproved program; or 4) rehabilitate the loans. ${ }^{438}$ Debtors would be limited to one reaffirmation. A subsequent bankruptcy discharge would render the debtor permanently ineligible to receive federal student loans.

\section{Scope}

The proposed framework would apply to federal loans only. Student loans secured in the private market would fall outside the framework's purview. The author believes that private loans should be dischargeable to the same extent as other unsecured debt. ${ }^{439}$ This view is influenced by the fact that eligibility for a private educational loan is based on a borrower's creditworthiness, not an "enlightened" policy of broadening educational access. As such, private lenders are able to minimize their exposure to credit risks. Thus, these loans should not be given the same special treatment afforded federal loans, the vast majority for which creditworthiness is not considered.

\section{B. Issues Affecting Framework Implementation}

Implementation of the proposed framework would be affected mainly by issues related to costs and politics.

\section{Costs}

A potential criticism of the framework is that it would increase the cost of bankruptcy, thus, disadvantaging the debtors it seeks to help. In the aftermath of the 2005 Act, filing bankruptcy became more expensive both

${ }^{438}$ U.S. DEP'T OF EDUC., FED. STUDENT AID, GOING BACK TO SCHOOL, available at http://www2.ed.gov/offices/OSFAP/DCS/going.back.to.school.html. See also, U.S. DEP'T OF EDUC., FED. STUDENT AID, LOAN REHABILITATION, http://www2.ed.gov/offices/OSFAP/DCS/rehabilitation.html (describing loan rehabilitation as making "at least nine [9] full payments of an agreed amount within twenty [20] days of their monthly due dates over a ten [10] month period").

${ }^{439}$ Prior to 1984, student loans obtained from an entity other than a "non-profit institution of higher education" were treated the same in bankruptcy as other unsecured debt. However, Congress eventually granted private student loans equivalent status to federal student loans in bankruptcy. See, e.g., Student Loan Bankruptcy Exception, FINAID, available at $\mathrm{http}: / / \mathrm{www}$.finaid.org/questions/bankruptcyexception.phtml. 
in terms of filing fees and the cost of legal representation. ${ }^{440}$ Filing fee increases were statutory in nature. ${ }^{441}$ Increases in attorney's fees, while not technically statutory, were nonetheless the result of the Act's heightened reporting and disclosure obligations. These obligations, including those related to the means test, "increased the average amount of time an attorney spent on each case", and thus resulted in higher fees. ${ }^{442}$

Proving eligibility for discharge under this framework would of course require an attorney's time. But whether that time commitment would be greater than what is already dedicated to determining undue hardship is unknown. One of the benefits of the framework is heightened simplicity and efficiency. Thus, it seems entirely possible that the framework could lead to less time expended by attorneys determining their client's eligibility for discharge. If so, lower attorney's fees could result.

\section{Political Environment}

As discussed earlier, the implications of student loan indebtedness have taken on heightened prominence as debt levels have increased drastically. Proposed solutions to student loan overindebtedness are varied, ranging from an expansion of income-based repayment options, ${ }^{443}$ to a call for forgiveness of all student loan debt, ${ }^{44}$ to a counterproductive encouragement of voluntary defaults by student loan debtors. ${ }^{445}$ There are even some who believe the federal government should get out of the student loan business altogether. ${ }^{446}$ Passions run high on all sides. Thus, proposed

\footnotetext{
${ }^{440}$ U.S. GOV'T ACCOUNTABILITY OFFICE, GAO-08-697, BANKRUPTCY REFORM: DOLLAR COSTS ASSOCIATED WITH THE BANKRUPTCY ABUSE PREVENTION AND CONSUMER PROTECTION ACT OF 2005, 4 (2008), available at http://www.gao.gov/new.items/d08697.pdf (concluding that attorney's fees rose an average of $51 \%$ in Chapter 7 cases and 55\% in Chapter 13 cases, while filing fees rose $43 \%$ in Chapter 7 cases and $41 \%$ in Chapter 13 cases).

${ }^{441}$ Id. at 5 .

${ }^{442}$ Id. at 27.

${ }^{443}$ See, e.g., COLlEgE BoARd, Fulfilling the COMMITMENT: RECOMMENDATIONS FOR REFORMING FEDERAL STUDENT AID 18 (2008), available at http://professionals.collegeboard.com/profdownload/rethinking-stu-aid-fulfillingcommitment-recommendations.pdf.

${ }^{444}$ Robert Applebaum, Obama's Student Loan Reforms: Right Problem, Wrong Solution, FORGIVESTUDENTLOANDEBT (Oct. 28, 2011), available at http://forgivestudentloandebt.com/content/obamas-student-loan-reforms-right-problemwrong-solution.

${ }^{445}$ See, e.g., Lynn O'Shaughnessy, Is Occupy Student Debt Pledge Drive a Bust?, CBSNEWS (Dec. 12, 2011), available at http://www.cbsnews.com/8301-505145_16257341046/is-occupy-student-debt-pledge-drive-a-bust/.

${ }^{446}$ See, e.g., Richard Vedder, Subsidizing the College Bubble, N.Y. TIMES (Oct. 27, 2011),
} 
reforms often elicit fierce support and even fiercer criticism.

Given that the solvency of the student loan system has been an enduring, though exaggerated, justification for restricting discharge of student loan debt, the proposed framework was developed paying particular attention to ensuring that only debtors who are legitimately facing crushing debt and few prospects for repaying it would be incentivized to seek discharge. The framework acknowledges that many student loan debtors would benefit from bankruptcy relief, but also appreciates that a limitless expansion of such relief would be both inadvisable and politically untenable.

\section{CONCLUSION}

With the cost of higher education and reliance on student loans both rising, an increasing number of debtors will become overburdened with student loan debt. This trend will be exacerbated by dismal educational outcomes, stubbornly high unemployment, and stagnant wages. As such an increasing number of student loan debtors will seek out bankruptcy relief.

The proposed framework was developed to effectively address this trend by rendering the bankruptcy system fairer to federal student loan debtors and their creditors - essentially, the taxpayers. The current system of determining undue hardship is rife with ambiguity and subjectivity; therefore, it should be undone, replaced by a framework that relies on objective measures and lends itself to impartiality, economy, uniformity, and simplicity.

available at http://www.nytimes.com/roomfordebate/2011/10/27/should-college-grads-geta-break-on-their-loans/subsidizing-the-college-bubble. 